\title{
Formation of Identities of Bangladeshi Immigrants in Ottawa
}

\author{
By
}

\section{Kazi Afzal Ahmed}

B.S.S. Hons. M.S.S.

A thesis submitted to the Faculty of Graduate Studies and Research in partial fulfillment of the requirements for the degree of

\section{Master of Arts}

Department of Sociology and Anthropology

\author{
Carleton University
}

Ottawa, Ontario

January, 2006

(C)2006, Kazi Afzal Ahmed 


$\begin{array}{ll}\begin{array}{l}\text { Library and } \\ \text { Archives Canada }\end{array} & \begin{array}{l}\text { Bibliothèque et } \\ \text { Archives Canada }\end{array} \\ \begin{array}{l}\text { Published Heritage } \\ \text { Branch }\end{array} & \begin{array}{l}\text { Direction du } \\ \text { Patrimoine de l'édition }\end{array} \\ \begin{array}{l}\text { 395 Wellington Street } \\ \text { Ottawa ON K1A ON4 } \\ \text { Canada }\end{array} & \begin{array}{l}\text { 395, rue Wellington } \\ \text { Ottawa ON K1A ON4 } \\ \text { Canada }\end{array}\end{array}$

Your file Votre référence ISBN: 978-0-494-16417-4 Our file Notre référence ISBN: 978-0-494-16417-4

NOTICE:

The author has granted a nonexclusive license allowing Library and Archives Canada to reproduce, publish, archive, preserve, conserve, communicate to the public by telecommunication or on the Internet, loan, distribute and sell theses worldwide, for commercial or noncommercial purposes, in microform, paper, electronic and/or any other formats.

The author retains copyright ownership and moral rights in this thesis. Neither the thesis nor substantial extracts from it may be printed or otherwise reproduced without the author's permission.
AVIS:

L'auteur a accordé une licence non exclusive permettant à la Bibliothèque et Archives Canada de reproduire, publier, archiver, sauvegarder, conserver, transmettre au public par télécommunication ou par l'Internet, prêter, distribuer et vendre des thèses partout dans le monde, à des fins commerciales ou autres, sur support microforme, papier, électronique et/ou autres formats.

L'auteur conserve la propriété du droit d'auteur et des droits moraux qui protège cette thèse. $\mathrm{Ni}$ la thèse ni des extraits substantiels de celle-ci ne doivent être imprimés ou autrement reproduits sans son autorisation.
In compliance with the Canadian

Privacy Act some supporting forms may have been removed from this thesis.

While these forms may be included in the document page count, their removal does not represent any loss of content from the thesis.
Conformément à la loi canadienne sur la protection de la vie privée, quelques formulaires secondaires ont été enlevés de cette thèse.

Bien que ces formulaires aient inclus dans la pagination, il n'y aura aucun contenu manquant. 


\begin{abstract}
$\underline{\text { Abstract: }}$
The goal of this ethnographic research on formation of ethnic identities of Bangladeshi immigrants in Canada, with a particular focus on the Ottawa community, is to explore how Bangladeshi immigrants construct, select, negotiate, and communicate their ethnic identity. Based on participant observation fieldwork this research focuses on the community organizations of Bangladeshi immigrants in Ottawa because these organizations play a significant role in the construction of their ethnic identity. In the process of formation of organizations, Bangladeshis in Ottawa draw on political and religious ideologies dominant in Bangladesh, generate social class distinctions and produce factions within the community. The thesis investigates the factors behind the construction of ideologies and factions within the community, and their connection to the ideologies and events happening in Bangladesh and other parts of the globe.
\end{abstract}


Dedication:

To my parents

Shamsunnahar Lasker

and

Late Kazi Mahiuddin Ahmed

Reproduced with permission of the copyright owner. Further reproduction prohibited without permission. 


\section{Acknowledgements:}

I would like to express my gratitude to a number of people who were instrumental to the completion of this work. I first wish to thank my co-supervisors: Blair Rutherford and Brian J. Given. Thank you very much for your support, guidance, advice, and encouragement throughout this process. I am greatly appreciative of your effort and time invested throughout this process.

I would like to express my gratitude to my wife Saleha Money Islam and my son Arithro Nishonku Kazi. Your presence in my life is enriching and inspirational.

Finally, I would like to express my deepest thanks to all of the participants of Bangladeshi community in Ottawa who contributed their time, energy and thought. 


\section{Table of Contents}

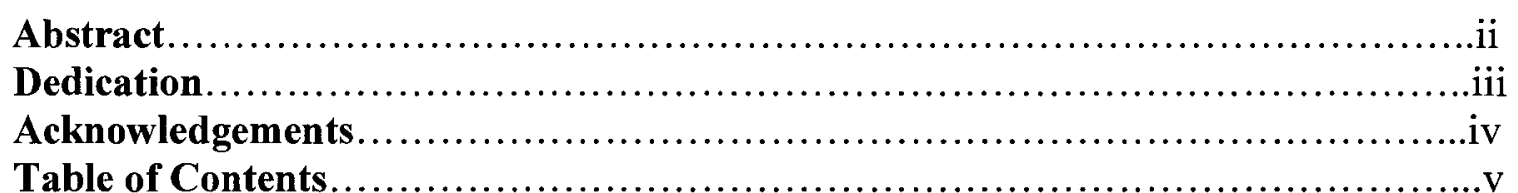

Chapter-1: Introduction.................................................. 1

1.1 An overall idea about the topic, central research question and the rationale of the study

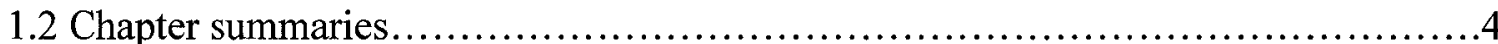

Chapter-2: Review of Literature and Methods of Study .......................... 10

2.1 Literature on ethnicity and identity ........................................ 10

2.2 Literature on Canadian Immigration policy and its impact on the Bangladeshi immigrants.......................................................................13

2.2.1 A Brief History of Immigration and Settlement in Canada.................14

2.2.2 Since September 11, 2001.............................................. 17

2.2.3 Impacts on Canadian Society............................................18

2.3 Related studies concerning Bangladeshi immigrants ............................... 19

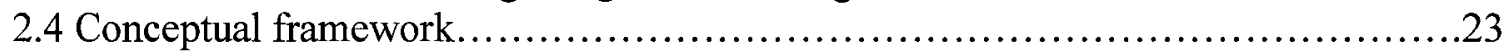

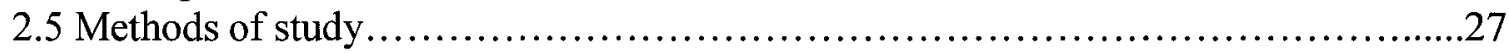

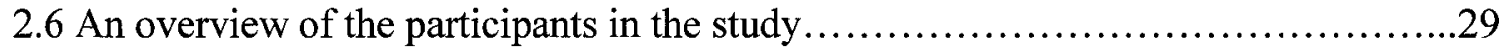

Cahpter-3: History and background of Bangladeshi Immigrants................... 31

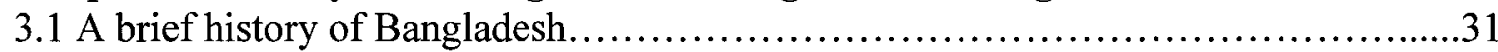

3.2 A general idea about the Bangladeshi immigrants in Ottawa........................35

3.2.1 The processes of Bangladeshi people's immigration in Canada..............36

3.2.2 Adaptation in the new environment.....................................444

3.2.2a Making a living ...........................................44

3.2.2b Finding Employment..........................................46

$3.2 .2 \mathrm{c}$ Other adaptation factors..................................46

3.2.3 Expectations and status dislocation.................................47

3.2.4 Construction of community, organization and association.................49

Chapter-4: Choice of Ideologies, Organizations and Conflict: Construction of Local

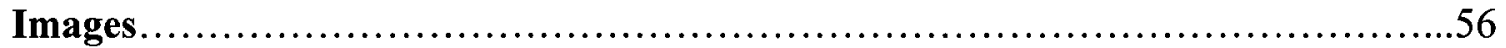

4.1 Bangladeshi Community organizations in Ottawa...............................57

4.1.1 Case Study: Bangladesh Association in Ottawa (BAO) ....................57

4.1.2 Construction of social classes: struggle for power.......................58

4.1 .3 Emergence of religion...............................................60

4.1.4 Confrontation and negotiation of 'Islamic' and 'non-Islamic' values.....63 
4.2 Ideology-based organizations: response to the incidents in Bangladesh and in other

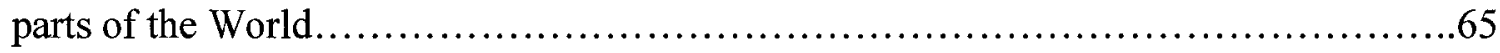

4.2.1 Factions within organizations: social class revisited....................66

4.2.2 The organizers.................................................67

4.2.3 Constructing solidarity and differences within the community................68

4.3 Factors behind organizations and groups in the community........................69

4.3.1 Political and ideological interpretation or reconstruction.....................71

4.3.2 Importance of local images..........................................80

4.4 Factors behind the construction of ideologies................................ 82

4.4 .1 Social stratification.................................................88

4.4.2 Timeframe of immigration and suffering in Bangladesh................ 83

4.4.3 Attacks on 'Bengali' culture in Bangladesh.............................. 84

4.4.4 Relationships to the political parties of Bangladesh.....................85

4.4.5 Global incidences and their effects......................................86

4.4 .6 Feeling of Discrimination........................................ 87

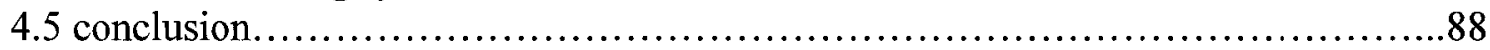

Conclusion.................................................................... 90

Appendix: Glossary of Terms and Events used in this Thesis...............................93

Bibliography.......................................................... 97 


\section{Chapter 1: Introduction}

Bangladesh came into being at the cost of a lot of bloodshed in 1971. Today, Bangladesh is considered one of the poorest countries in the world. Around 150 million people live in Bangladesh. A number of people from Bangladesh have usually gone abroad in search of a better life. A large segment of these fortune seekers have come to Canada. Generally, the people of Bangladesh have an optimistic image about 'foreign-life'. Some people are ready to leave the country even risking their own lives. It is a common news story that a person from Bangladesh has sold all of his possessions to go abroad or that some people from Bangladesh have died in the pursuit of reaching a foreign country. I have chosen to carry out my ethnographic research concerning Bangladeshi immigrants in Ottawa. For the purpose of understanding the ethnic identity, it is an important to examine how Bangladeshis construct, select and practice their ideologies in personal and organizational level in Ottawa. Ethnicity tied to events in Canada, and ideological divisions in Bangladesh is a key strategy used by Bangladeshi immigrants to adapt to Ottawa, particularly in terms of formation of community organizations.

The goal of this ethnographic research on formation of ethnic identities of Bangladeshi immigrants in Canada, with a particular focus on the Ottawa community, is to explore the process whereby Bangladeshi immigrants select, negotiate, and communicate their ethnic identity. Bangladeshis started to immigrate to Canada in the 1960s (Nazneen, 2003), when the Canadian government introduced a new system of evaluation for immigration; that is, a "point system" which assesses all immigrants on the same skills and training-related criteria (Abu- 
Laban \& Gabriel, 2002:43). Besides the professional immigrants, there are some other categories of immigrants such as sponsored family category immigrants, business category immigrants, employment insurance program category immigrants, and refugees. Whatever the process of entrance, after a time period immigrants can receive Canadian citizenship. Usually immigrants can apply for citizenship after three years of living in Canada. Generally, immigrants have a tendency to identify themselves as a Canadian with a hyphenated country of origin, language or religion. Obviously, however, the group is not homogeneous since there are many differences within the community such as length of residence in Canada, categories of immigration, levels of education, gender, and generation and other distinctions that may be recognized in their country of origin.

Two major ideologies, 'secularism' and 'religiosity' (e.g. Islam), are very important within the Bangladeshi community in Ottawa in terms of distinctions related to debates within Bangladesh. Those are the core ideas whereby people are united and divided within the Bangladeshi community in Ottawa. These ideas seem to be rooted in the birth and the politics of Bangladesh. The ideologies are the key element in the establishment and maintenance of the community organizations in Ottawa. The 'Islamist' approach provides spiritual as well as social guidance and services. On the other hand, the 'secularist' approach is trying to increase awareness of the 'Bengali' culture and history to promote connections among Bangladeshis.

Though there are no official statistics on the number of Bangladeshi immigrants in Ottawa, community people of Bangladesh estimate that there are around five thousand Bangladeshi immigrants living in Ottawa. However, little has been written about them as of 
yet. Bangladeshi immigrants in Canada often become lost in the shadow of other larger South Asian ethnic groups (Ahmed 1993:13). This research investigates the core values and markers of ethnicity of Bangladeshi immigrants in Ottawa. To better understand the issues, it is important to find out: 1) the personal use of ethnic markers of the Bangladeshi immigrants; 2) the process of construction of community; and 3) the processes of selection and negotiation of their ethnic identity that may be a product of an interaction between personal and community based processes of adaptation to the Canadian society.

The majority of the population in Bangladesh are Muslim. Naturally, the majority of the Bangladeshi immigrants in Ottawa are also Muslim. On September 11, 2001, an attack occurred on the U.S.A. which killed thousands of people. The people behind the attack have been publicly identified as "Muslims". After the incident, the religion of Islam has taken a new significance in various spheres including academic discussions. It is usually thought that Afghanistan and Iraq, which are predominantly Muslim countries, have been invaded as an aftermath of 'September 11.' From media and academic discussions it is found that all over the globe including Canada, many Muslims were physically and mentally assaulted after 'September 11.' According to Nahla Abdo (2002: 375):

...many attacks were made on young Arab men and women. For example, a Saudi female doctor was repeatedly attacked in an elevator in a hospital in Montreal, while other Arab and non-Arab Muslim students were harassed at schools, in streets and in the neighborhoods. A couple of cases of attack on young Arab students were reported in Ottawa; one in the area of Nepean and the other outside a shopping mall in the city. The cultural institution, the Museum of Civilization, itself designed by a Native architect to symbolize "multicultural harmony", took an unprecedented decision to postpone indefinitely an art show which had been in the making for over five years. 
Bangladeshi immigrants in many informal discussions claim that they have been facing an array of problems for their 'Muslim' identity after 'September 11'. These problems include a lack of employment or unjustified dismissal from employment. This thesis attempts to find out how Bangladeshi immigrants go about facing these difficulties. The estimation of these problems or difficulties may differ from person to person. When Bangladeshi immigrants adopt strategies to face their problems, their estimation of the problems plays a significant role. This thesis aims at looking at the reasons behind these differences; particularly in the formation of community organizations in Ottawa. This thesis also seeks to find out whether the different criteria of estimation used by Bangladeshi Canadians have any connection with Bangladesh. Another purpose of the thesis is to find out whether these problems play a role in determining the identity of Bangladeshi immigrants.

\subsection{Chapter Summaries}

Chapter two consists in a review of the literature. The purpose of this chapter is to ensure clarity of terms and ideas that are used throughout the thesis. The first part of this chapter discusses different approaches towards ethnicity and identity. There are no universally accepted criteria for ethnic identity. Isajiw (1999) identified four approaches towards ethnicity. The approaches cover most of the theories in ethnicity studies.

Among the four, situational approach is important in this research. According to this approach ethnicity is something that can be chosen by a member of a group and that may be relevant in some situations but not in others. Ethnic identity is related to the requirements of social situations (Isajiw 1996: 31). Changed social and political situation can affect the 
identity of individuals and people can adjust their identity in accordance with the situation. However, the constructivism approach also has a significant role in the estimation of situation. This approach focuses on the ways ethnic identity is built and rebuilt. Stuart Hall (1996:2) sees identity as a construction, a process never completed- always 'in process'. The basic notion in this approach is that ethnicity is something that is being negotiated and constructed in everyday living. In a changed situation, some of the common characteristics of an ethnic identity may be relevant in some places but may not be appropriate in other places. Circumstances may have a vital role in the selection and presentation of ethnic identity. It is important to study how people select the strategies to find out some common characteristics with other persons or groups and how they establish solidarity with some people and make distinction from others.

Later, the chapter offers a brief history of Canadian immigration policy and discussed its impact on Canadian society in general and Bangladeshi immigrants in particular. From discussion of Canadian immigration policies it can be said that global political and economic perspectives have impact on Canadian immigration policies in different time periods. In the same way, after 'September 11, 2001' some of the policies on immigration and security had been changed. These changes affected all of the Muslims including Bangladeshi immigrants.

A conceptual framework is also introduced in this chapter. Usually immigrants tend to actively seek a historical past, language and culture in their country of origin. Immigrant's identities therefore may be constituted within the community. The identities relate to the invention of tradition as much as tradition itself; "not the return to the roots but to find the 
'routes" (Hall 1996: 5). Global-local issues become important in recent years to understand the changing world in the age of globalization. Dirlik (1996: 27) suggested that while "home" or "domestic" or "local" refers to traditionalism, minority, and religiosity; "away" or "foreign" or "global" refers to space, power, capital, and history. However, according to Wilson and Dissanayake (1996: 1), global issues affect the locals in various ways and in response to them locals are constructed. Escobar $(2001: 141)$ argued people continue to construct some sort of boundaries around their places and these are grounded in local sociocultural practices. He stated that both place or local and space or global are important to understand the changing cultural components in the age of globalization.

Place is not fixed, permanent, or unconstructed. Place is not always only local and space is not always only global. It is important to find out how people practice the local in the global, that is, of examining the practices through which people construct places even as they participate in space networks. Politics and power are also located in place, not only space. According to Dirlik (2001:16), to give attention to both "localization of global" and "globalization of local", the term "glocal" can work appropriately. This term seeks to problematize the binary opposition of the local and the global. This "glocal" strategy engages in the production of locality in the global by engaging diversified networks with other places. On the other hand, John Eade and David Garbin (2002) discuss the notion of "glocalization" not as a model of binary opposition but as a process that involves the reconstruction, in a sense the production of home, community and locality. They suggest against the image of local practices struggling against the hegemonic power of global forces, there is a more complex process of interaction. This image involves in the reconstruction, in a sense of the 
production of 'home', 'community' and 'locality' (Robertson 1992:30, quoted in Eade and Garbin 2002:137). This 'locality' is related to a transnational link but concentrate their operations locally. The similarity and differences, unity and partition and the cultural 'heritage' are rooted in country of origin and at the same time are affiliated to other local and global issues. At the end of this chapter there is a discussion on the methods of the study and an overview of the participants.

Chapter three introduces the history and background of the Bangladeshi immigrants. The history of Bangladesh is summarized for a better understanding of Bangladeshi immigrants in Ottawa. For this reason a brief history of the Bangladeshi state, major political incidents of Bangladesh and a brief idea about the culture of the country are discussed in this chapter. Bangladesh became a sovereign country after a bloody war in 1971. Major political incidents including the war affected many people of Bangladesh. Some of them left the country as a consequence of these incidences and arrived in different countries, including Canada. There are different processes of arriving in Canada. It is important to look at how Bangladeshis adapt themselves in the new environment in Ottawa, what kind of expectations they had and how these expectations have also faded. According to the participants in the study, all of them have experienced some difficulties in the new environment. To overcome the difficulties and to share their experiences Bangladeshi immigrants in Ottawa tried to construct different types of organizations and associations. For the purpose of strengthening their community Bangladeshis have been trying to form these organizations. Most of the respondents aspire to having a strong community organization in Ottawa where all Bangladeshis will be involved and in which community members help each other to survive 
and settle here in Ottawa. However, when members of the Bangladeshi community formed the organizations, there were divisions due to conflict over leadership and power, connected to the grounding ideological divide in Bangladesh between 'secularism' and 'Islam'. These conflicts divided the community as a whole.

Chapter Four lays out the basic findings and analysis of the research. Many of the Bangladeshis are involved in their community organizations active in Ottawa. The leaders seem to select some political and religious ideologies in the formation of their community organizations. These ideologies are related to the politics and religion in Bangladesh. Differences of these ideologies produce conflict within the Bangladeshi community in Ottawa. As a result Bangladeshi immigrants in Ottawa constructed different kinds of community organizations. To understand the factors behind the ideological choices as well as construction of identity, study of community organizations are very important. The images of Bangladesh have a significant impact on the construction of the community organizations on the one hand on the other, global incidents also produce different types of activities in the community.

Chapter Five contains the conclusion of the thesis. In this chapter, I offer my views, based on experiences with the Bangladeshi immigrants in Ottawa. Leaders of Bangladeshi community organizations established a sharp distinction among the community and encourage activists to emphasize the differences between 'secularism' and 'Islamism'. Both 'Islamists' and 'secularists' are concerned about the same issues- racial discrimination, education, 
unemployment- but they are beginning to diverge when they consider the reasons for choosing the strategies to fight against them. 


\section{Chapter 2: Review of Literature and Methods of Study}

The goal of this ethnographic research on formation of ethnic identities of Bangladeshi immigrants Ottawa is to explore the process whereby Bangladeshi immigrants select, negotiate, and communicate their ethnic identity. For a better understanding of this issue it is important to be familiar with the literature concerning ethnicity, the immigration policy of Canada and other literature relating to Bangladeshi immigrants. This chapter discusses different theories concerning ethnicity, immigration policies of Canada, methods of the study and literature relating to Bangladeshi immigrants.

\subsection{Literature on ethnicity and identity}

There are no universally accepted criteria for ethnic identity. The criteria used for defining ethnic identity may vary from group to group in relation to time and place and reflect pressures from the larger society. Ethnic identity is defined as the part of the totality of one's construct of the self, made up of those dimensions that express the continuity between one's construal of past ancestry and one's future aspirations in relation to ethnicity (Weinreich, 2003:78).

Isajiw (1999) identified four approaches which takes ethnicity to be: (1) a primordial phenomenon (2) an epiphenomenon (3) a situational phenomenon or (4) a subjective phenomenon. The primordialist approach, also known as the 'essentialist' approach, argues

that ethnicity is something given, ascribed at birth, deriving from a kin structure of society. It is more or less something fixed and everlasting. This includes the shared history and the 
origin of the group into which the person is born, the group's nationality, language, belief, custom, and value system. These all significantly contribute to shaping the person's attitude, lifestyle and sense of identity (Isajiw 1999:29). According to this approach the factors mentioned above form peoples behaviour, lifestyle and identity.

The epiphenomenon approach originated from Marxist theory that constructs ethnicity as the by-product of class relations; ethnic relations are one aspect of exploitation of labor by the capitalist class. During the 1970s some theorists laid emphasis on internal colonialism and the cultural division of labor. They argued that the economic structure of society is divided into two sectors, centre and periphery. Peter Li (1990:15) argued:

Ethnicity is the consequence of unequal relationships, produced and maintained by differential power between a dominant and subordinate group. Distinct cultural and racial differences are developed and used as convenient grounds for justifying the exploitation of subordinate groups by super ordinate groups.

Therefore, according to the epiphenomenon approach, ethnicity is something created and maintained by an uneven economy, a product of economic exploitation. The people who concentrate in the peripheral labour sector become an ethnic group. Ethnicity thus refers to minority groups only.

According to the situational approach, ethnicity is something that can be chosen by a member of a group and that may be relevant in some situations but not in others. Individuals may choose to be regarded as members of an ethnic group if they find it advantageous. According to this approach, ethnic identity is related to the requirements of social situations 
(Isajiw 1996: 31). Changed social and political situations can affect the identity of individuals and people can adjust their identity in accordance with the situation.

Point of view is the basis of subjectivist approach. This approach sees ethnicity as a social and psychological reality or a matter of perception of "us" and "them". Fredrik Barth's (1969) work on ethnic group boundaries had a strong influence on this approach. For him, ethnic boundaries are psychological boundaries; ethnic culture and its content are not important. Collectivities are generated in and out of the interaction between individuals. Ethnic groups therefore result from the dynamics of group interaction in which the boundaries are established through mutual perceptions. Barth's key insight is that ethnic identities are flexible.

Connected with the post-modernist movement in contemporary thought, another kind of subjectivist approach is constructivism. This approach focuses on the ways ethnic identity is built and rebuilt. Identity is constructed on the back of recognition of some common origin or shared characteristics with other persons or groups (Isajiw 1999: 35). Stuart Hall (1996:2) sees identity as a construction, a process never completed- always 'in process'. The basic notion in this approach is that ethnicity is something that is being negotiated and constructed in everyday living.

In discussions of different approaches, we find that some fundamental questions are important in ethnicity studies. For example: What do we perceive that we have in common with members of other groups? How do we know who we are, and how do others identify us? 
How do we share aspects of our identity with many others? To find common aspects with other people and share these aspects may be related to the demand of situation. Some of the common origin or characteristics may be relevant in some places but may not be appropriate in other places. Circumstances may have a vital role in the selection and presentation of ethnic identity.

Ethnicity may be understood as a sense of ethnic identity. Ethnicity involves what we are or how we see ourselves, who others are, and what involve in living together. One of the important factors in this regard is our understanding of who we are and who other people are, and, reciprocally, other peoples' understanding of themselves and of others which includes us. But the presentation and negotiation of ethnic identity is not always simple or superficial but complex and is always in a process of construction. The introduction of a national policy of multiculturalism in Canada provided more inclusion of immigrants and ethnic and racial minorities. Generally, multiculturalism stands for a wide range of potential and existing process and public policies within a nation state wherein minority collectivities might gain recognition, protection and rights (Abu-Laban 2002:462). However, multiculturalism also identify 'majority' and 'minority' where immigrants are 'minorities' and they need an identity. Immigrants' identities may be constructed in the demand of their situation.

\subsection{Literature on Canadian Immigration policy and its impact on the Bangladeshi immigrants}

Since confederation in 1867, Canadian immigration policy favored British-origin white, Protestants, who were viewed as "model citizens" (Abu-Laban \& Gabriel 2002: 43). 
The introduction of a new evaluation system in the $1960 \mathrm{~s}$, the "merit point system" opened the door for people of many different origins. This system assesses all immigrants on same skill and training-related criteria (Isajiw1999: 85). This system incorporated the people from different racial and ethnic backgrounds, resulting in a more "multicultural" Canada. This system of immigration consolidated the mixture of race and ethnicity. However, the events of 'September 11' opened the hidden windows of divisive elements of Canadian society. After 'September 11' some incidents occurred against 'Muslims' in Canada; the government introduced new policies in the areas of security and immigration. Many attacks were made on Muslims in Ottawa and other parts of Canada (Abdo 2002: 375).

\subsubsection{A Brief History of Immigration and Settlement in Canada}

The original settlers in Canada were the Indians and Inuit, today called the Native or the First Nations or Aboriginal. The ancestors of Indians came to Canada probably around 40,000 B.C. and those of the Inuit around 8,000 B.C. (Isajiw 1999:77). The period of colonization of Canada by French, until the defeat of New France by the British in 1753 involves primarily two types of migrants, settlers and colonizers. The general feature that characterize this period is that settlement and immigration process were by and large aspects of the process of colonization (Isajiw 1999:78).

In 1952 a new Immigration Act was passed. It gave powers to the Minister of Immigration to admit or deny admission to immigrants on the basis of ethnicity, citizenship, peculiarity of customs, suitability as judged by immigration officials, probable inability to become assimilated and the like. In 1962 new immigration regulations were issued that, in principle, abolished all restrictions based on ethnicity. Instead the regulation addressed the 
economic needs of the country and established education, training and skill as the main criteria in the selection of un-sponsored immigrants. The Immigration Regulation of 1967 gave a new structure to Canadian immigration. They created a system of admissions to Canada based on merit points. The immigrants under this merit point system are defined as skilled workers. Skilled workers have education, work experience, knowledge of English and/or French and other abilities that will help them to establish themselves successfully as permanent residents in Canada. Under the Immigration Act of 1976 there was an explicit commitment to link immigration flow to economic conditions and to demographic needs. Furthermore the Act defined the family class of immigrants more specifically. Canadian citizens and permanent residents living in Canada, 18 years of age or older, may sponsor close relatives or family members who want to become permanent residents of Canada. Sponsors must promise to support the relative or family member and their accompanying family members for a period of three to 10 years to help them settle in Canada. Relatives or family members are spouses, common-law or conjugal partners 16 years of age or older; parents and grandparents; dependent children, including adopted children; brothers, sisters, nephews, nieces or grandchildren who are orphans. The category of "refugee" also was highlighted. Refugees are those people who according to the United Nation's definition have well founded fear of persecution in their homeland.

In addition to its well-established merit point system and in order to encourage migrants who would fill certain types of jobs for which there appeared to be a demand, in the early 1980s, the government introduced an employment authorization program. This program invited persons from outside of Canada to come to Canada to do designated types of work, 
particularly domestic work. Another special immigration program introduced in this period was an attempt to attract "business migrants", that is, persons who would come to invest money in Canadian businesses.

In 1993, a new amendment to the 1976 Immigration Act went into effect (Bill C-86). It gave the government the authority to set limits on the number of immigrants accepted in each specific category, including refugees and business immigrants. It also gave power, previously held by the determination boards, to the senior immigration officers at the point of entry to determine the credibility of refugee claims and it authorized the government to use various preventive measures to unearth potential illegal immigrants before they arrived in Canada. The revisions of the Act had many effects including: linking immigration more closely to population and labor market needs; providing for an annual announcement of the number of immigrants Canada could absorb following mandatory consultation with provincial and territorial governments and optional consultation with groups or individuals in the private and voluntary sectors; allowing Canadian citizens and permanent residents in Canada to sponsor close relatives; requiring immigrants and visitors to obtain visas or authorization abroad; introducing security measures to protect Canada from international terrorism and organized crime and measures to safeguard the civil rights of immigrants and visitors through a quasi judicial inquiry; providing short term alternatives to permanent deportation for cases involving less serious violations of immigration law; and spelling out in specific terms the powers granted to government official (CIC 1998:3 in Isajiw 1999:89). Within the policy environment contemporary construction of 'model citizen' also has been taking place by 
defining and choosing 'best', 'contributors to economy and society' etc. (Abu-Laban \& Gabriel 2002:61).

\subsubsection{Since September 11, 2001}

Bill C-11, The Immigration and Refugee Protection Act was introduced in 2001. It replaced the 1976 Immigration Act. The Immigration and Refugee Protection Act attempts a balance between two competing objectives; "opening the door" to the kinds of immigrants Canada desires and "closing the back door" to illegal immigrants (Abu-Laban \& Gabriel 2002:61). Some of the provisions in Bill C-11, such as identity cards for all permanent residents, have been fast-tracked as part of the governments' fight against terrorism. It added organized criminality and misrepresentation as new categories of inadmissibility. It should be noted in terms of security that the bill retained previously existing but undefined clauses that indicated that terrorism and membership in a terrorist organization also constituted grounds for inadmissibility. The control and security measures within Bill C-11 have been characterized as increasing penalties and reducing individual rights and protections for refugees and immigrants (Canadian Council for Refugees, 2001:1 in Abu-Laban \& Gabriel 2003:299). In the aftermath of 'September 11', the government repeatedly emphasized that its proposed immigration legislation would contribute to the security of Canada (Abu-Laban \& Gabriel 2003:301).

On October 2001, just after 'September 11', the government of Canada introduced Bill C-36, The Anti- Terrorism Act. One of the biggest issues was defining terrorism, which seemed to include both illegal strikes and civil disobedience. The bill stated that, "an act or 
omission---intended to endanger a person's life---(and) to cause serious interference with or serious disruption of an essential service" and an unlawful act committed for "ideological purpose" that causes "serious disruption of an essential service, facility or disruption" are part of terrorism (Anti Terrorism Act, Bill C-36 in Smith 2003:148). Beyond this some other powers and controls are unpleasant, they are: a) the power of detention- to allow holding a suspect without charge, with judicial approval, for 72 hours; b) the power to detain, without charge, with judicial approval, for up to one year, if the person does not agree to reasonable restrictions on his or her behavior as a condition of release; c) the possibility of up to ten years imprisonment for "legally" "participating or contributing" to activities of a known terrorist group; d) the requirement to testify at "investigative hearings"; and e) allowing the SolicitorGeneral the power of create a "List of Terrorists" on "reasonable grounds" only and then not require the government to even notify individuals or groups that they are on the list (Smith 2003:149).

\subsubsection{Impacts on Canadian Society}

People of different color, race, ethnicity, religion may deploy different subject positions and ideologies for strategic purposes. But the incidents of the 'September 11' affected public attitude towards Muslims throughout the globe, even in Canada. There were more than a hundred incidents of violence occurred in Canada after the incidence of 'September 11'. Muslim people, even bearded Sikhs were beaten, Hijab-wearing women were insulted, and a mosque was vandalized (Esses, Dovidio \& Hodson 2002:73). 
From a psychological perspective, Esses, Dovidio \& Hodson (2002) demonstrated that public attitude has changed in response to the events of 'September 11'. The impact involves an intense feeling of threat and distrust within the society. Perceptions and feelings of threat to one's group typically strengthen the sense of one's collective identity, which is reflected not only the solidarity of group, but also in enhanced motivations to see the in-group in more favorable terms than the out-group (Tajfel and Turner, 1979 in Esses, Dovidio \& Hodson 2002:74).

Canadian immigration policies were never separated from the forms of exclusion and inclusion. In different time periods those policies favoured some people to immigrate to Canada and created barriers to others. Those others were "Chinese", or "Asians", or "Japanese", or "Communists". All the groups were branded by the Canadian authority as 'criminals', 'enemies' or 'unqualified for the society'. The homogenous and structured approach concerning "Muslims" can function as a code to identify the "potential terrorists" of "Middle East" (Esses, Dovidio \& Hodson 2002:78). Therefore, the events of 'September 11' have an impact on the Canadian immigration policy which can affect all Muslims, including Bangladeshis who immigrated to Canada.

\subsection{Related studies concerning Bangladeshi immigrants}

For the purpose of understanding Bangladeshi immigrants in Ottawa, it is important to discuss previous studies concerning Bangladeshi immigrants. For this reason, findings of other research related to Bangladeshi immigrants in different parts of Canada and England are 
discussed in this section of the chapter. It is also discussed whether the findings of these studies are similar regarding Bangladeshis in Ottawa or there are differences.

Rahim (1991) stated that Bangladeshis in Toronto represent a community whose identity is rooted in a common origin. The primordial approach has a strong influence on Rahim's work. According to him, as the basis of the sociability, Bangladeshis have a strong sense of belonging to the culture of Bangladesh. Their mannerisms, customs, and method of social interaction are distinctly Bangladeshi. They have all retained some essential identity of their native land, and for them nothing seems stable and permanent in Canada. To him, it appears that the demands of the Canadian way of life were imposed on them, and contradictions were apparent in every aspect of their lives. Bangladeshi immigrants found pleasure and security in their traditions, which are remarkably self-contained. According to Rahim, a thin line has divided the Bangladeshi community in Toronto into two groups: the territorial group and the psycho-cultural group. The territorial group is known for its intense loyalty to Bangladesh as its only home. Its dedication and enthusiasm for the cause of Bangladesh are manifested by the level of participation in community activities such as the observance of Bangladeshi national days. In contrast, the psycho-cultural group rarely participates in community socio-cultural activities, though psychologically and culturally it identifies itself as Bangladeshi.

Though, according to Rahim, the identity of Bangladeshi immigrants in Toronto is more or less fixed and permanent, later he stated that Bangladeshi immigrants in Toronto feel insecure, and they are apt to look for an alternative culture to combat a utilitarian ideology 
among the new generation. He added, perhaps for this reason they are increasingly turning towards religion and thus, are becoming more religious in their adopted country than they were in Bangladesh. So far, according to Rahim, Bangladeshis in Toronto have maintained their aspects of identity by speaking Bangla (Bengali) at home, teaching their children to read Holy Scriptures, giving exposure to Bengali culture, socializing with other Bangladeshi families, marrying within the community, or bringing their spouses from Bangladesh. $\mathrm{He}$ stated that a community organization named Bangladesh Association in Toronto has begun to reach out to the Bangladeshi community in Toronto and its surrounding areas, and as a result, the locus for cultural maintenance has shifted from the family to the association. From the discussion of Rahim it can be said that practiced tradition of Bangladeshi immigrants in Toronto is an invention as much as tradition itself 'not the return to the roots but to find the routes' as stated by Stuart Hall (1996:5). Bangladeshi community organizations in Ottawa are also concerned about 'traditional' Bangladeshi culture. However, there are differences of opinions in identifying this 'tradition'. 'Islamists' in Ottawa emphasize Islam in identifying and selecting the 'traditional' culture or ideology of Bangladesh. On the other hand 'secularists' emphasize on ideologies related to the 'liberation war' of Bangladesh in 1971. As a result, a number of organizations formed in the name of Bangladeshi culture have had differences of opinion which has created division within the community.

Ahmed (1993: 8) stated that prior to independence in 1971, Bangladeshi immigrants in the Toronto area were describing themselves generally as either Pakistanis or Indians. Education and income play significant role in the Toronto Bangladeshi community in terms of maintaining social relations with others which is related to the epiphenomenon approach 
discussed before. Ethnic associations of Toronto play an important role in the initial adjustment process for immigrants as well as later in reinforcing individual ethnic identity. Ahmed (1993:144) argued that the longer immigrants are away from their country of origin, the greater is the possibility that their sense of ethnic identity would change, which may not be true in the case Bangladeshi community in Ottawa. Rather many Bangladeshis who have been living in Ottawa for long time are closely involved in the formation of community organizations. The organizations are actively reproducing or inventing a culture which has a close relation to the events and politics in Bangladesh. However, Ahmed stated that Bangladeshi people in Toronto tend to have a strong identification with their country of origin, despite experiencing better living conditions here in comparison to living conditions in Bangladesh.

Nazneen (2003) argued that changing political and cultural situations shape the identity of Bangladeshi immigrants in Canada. She stated the identity of Bangladeshi immigrants in Canada is a tool for individuals to avoid pressures. According to Nazneen, to identify themselves, Bangladeshi immigrants in Montreal prefer their religion than any other ethnic phenomena. As argued by Nazneen, it is a commitment to ethnicity that allows an escape from a feeling of irrelevance and powerlessness in their new country. Situational approach has a strong influence on Nazneen's discussion. According to the approach ethnic identity is related to the requirements of social situation. Nazneen also discussed that a prominent global issue, 'the September 11, 2001 terrorist attack on USA', and its responses affected 'Muslim' people, including Bangladeshi Muslims in Montreal in many ways. They feel insecure because of their Muslim identity. As a result, some of the Bangladeshi 
immigrants in Montreal, religiously Muslims, become more religious and associate themselves with other Muslims from different national origins. Their Muslim identity is more powerful than Bangladeshi identity and it can support the fight against the discrimination and unfairness (Nazneen 2003:6). The community is constructed in the global city in relation to their origin of country and other religious groups, what Stoller and McConatha $(2001: 652)$ called a "community of mind".

In the same way Glynn (2002) found that young Bengali Muslims in England are being increasingly attracted to Islam due to an aspiration that this can benefit both themselves and the wider Bengali community. She stated that internationally oriented Islam has significant impact on the selection of identity. Some of the Bangladeshis in Ottawa are trying to uphold a 'Muslim' identity because it is more powerful than Bangladeshi identity as Nazneen stated. But the reason behind the tendency is not only the 'discrimination and unfairness' in Canada but also an outcome of the conflict within Bangladeshi community in Ottawa and rooted in the ideological differences of Bangladesh. Some of the Bangladeshis in Ottawa tend to emphasize more on the 'secular' cultural identity of Bangladesh. However, as stated by Nazneen, the incident of "September 11" has a strong impact on the selection of identity of Bangladeshis in Ottawa. Both the 'Islamist' and 'secularist' groups of people are concerned about the consequences of the incident of "September 11", but the ways they choose to face the problem are different. Glynn (2002) said that the socio-political incidents in Bangladesh also play an important role in the process of selection of identity. 


\subsection{Conceptual framework}

To understand the changing world in the age of globalization, global-local issues become important in recent years. Dirlik (1996: 27) suggested that to understand the changing world in the age of globalization, place-based analysis of identity becomes significant issue. While "home" or "domestic" or "local" refers to traditionalism, minority, and religiosity, "away" or "foreign" or "global" refers to space, power, capital, and history. Many scholars are now aware of the fact that global processes have changed the principal components of culture. It is a new world-space of cultural production and national representation, which is simultaneously becoming more globalized (unified around dynamics of capitalogic moving across borders) and more localized (fragmented into contestatory enclaves of difference, coalition, and resistance). According to Wilson and Dissanayake (1996: 1) global issues affect local ones in various ways and, in response to them, locals are constructed. Escobar (2001:141) argued people continue to construct some sort of boundaries around their places and these are grounded in local socio-cultural practices. He stated that both place or "the local" and space or "the global" are important in this regard. Escobar added,

Place is not 'the other' of space- place as pure and local and in opposition to a dominating and global space- since place is certainly connected to, and to a significant extent produced by, spatial logics. It is to assert, on the contrary, that place-based dynamics might be equally important for the production of space, or at least they are in the view of some place based social actors (Escobar 2001:147).

But speaking about place in this way does not mean that place is fixed, permanent, or unconstructed. It does not mean that place is always only local and space is always only global. It is important to find out how people practice the local in the global, that is, of examining the practices through which people construct places even as they participate in space networks. Politics and power are also located in place, not only the space. 
Dirlik (2001: 16) stated that to give attention to both "localization of global" and "globalization of local", the term "glocal" can work appropriately. This term challenges the binary opposition of the local and the global. Places are not given but produced by human activity, which implies how we imagine places. This "glocal" strategy is a social movement that engages in the production of locality in the global by engaging diversified networks with other places.

To understand the Bangladeshi immigrants in England, John Eade and David Garbin (2002) discuss the notion of "glocalization" as a process that involves reconstruction, in a sense of the production of home, community and locality. They suggested that contrary to the image of local practices struggling against the hegemonic power of global forces, there is a more complex process of interaction. This image involves in the reconstruction, in a sense of the production of 'home', 'community' and 'locality' (Robertson 1992:30, quoted in Eade and Garbin 2002:137). This 'localities' are related to transnational links but concentrate their operations locally. But the service they provide and the global connection they encourage diversify a lot. The identity of Bangladeshi immigrants has to be understood, therefore, according to different interconnected arenas such as local, national, regional and transnational and the images of those arenas.

From the discussion of Bangladeshi immigrants in Canada and other areas, it can be said that the Bangladeshi immigrants aspire to strengthen the community. The similarity and differences, unity and partition and the cultural 'heritage' are rooted in Bangladesh and at the 
same time are affiliated to other local and global issues. The events are not fixed or permanent. The people are practicing and constructing the local in the context of global processes and at the same time they may be constructing a different type of global connection. This global connection may have an influence on the construction of community. The constructionism approach, mentioned above, is a significant approach in this research. It is important to study how people select ethnic strategies to find out some common characteristics with other persons or groups and how they establish solidarity with some people and distinction from others. In the process of construction of community or group it is essential to find out the factors important in this regard. It is also important who leads the construction of the community. The construction and negotiation in everyday life is also related to the situational approach, where ethnic identity is chosen by a person according to the requirements of social situations. A person can choose identity that is relevant in some situations but not in others. The construction of community may not be permanent and solid, as fluidity is a characteristic of community construction. The Bangladeshi immigrants may select, negotiate and project their identity in relation to the place of projection or negotiation. Historical issues, such as 'globalization', 'the 9/11 attack on USA', and 'the crisis in the Middle East' may produce different types of activities. These activities are related to the concept of "glocal" where people are engaged in the production of a different type of locality that is rooted in their new 'local' of Ottawa and their country of origin, making diversified networks within other places. The construction of identity, related to inter-place relationship, is simultaneously the construction of the local and a new pattern of global. This new pattern of global provides a person or group a type of power in mind- this power is spiritual, religious, 
and also political. It produces simultaneously sameness with some people and also differences with others.

In studying ethnic identity of Bangladeshi immigrants, it is important to put together a combined approach, which covers the different types of construction, selection and negotiation of identity. It is necessary to study how ethnic identities are built and rebuilt, construction of recognition of some common origin or shared characteristics with other persons or groups. Community organizations play a central role in this process of construction, selection and invention of origin. There are different organizations active in Ottawa, which uphold certain ideologies of Bangladesh such as 'secularism' and 'Islamism'. For this reason, it is essential to study the community organizations of the Bangladeshi immigrants, in which the immigrants involve in the process of reconstruction, selection and negotiation of their identity.

\subsection{Methods of the study}

Participant-observation fieldwork is the main method of this research. Since early 2004 when I had decided to carry out my research on formation of ethnic identity of Bangladeshi immigrants in Ottawa, I have been trying to become familiar with the experiences and way of life of the Bangladeshis in Ottawa. I have been living in an apartment building where more than twenty families are Bangladeshi. From May 2004 to September 2004, I also acted as a participant observer within the Bangladeshi community in Ottawa. I have attended various community gatherings including cultural and religious programs, birthdays, marriage anniversaries and marriage ceremonies and other community gatherings. 
Attending these activities provided me with an opportunity to gain first-hand experience of and insight into Bangladeshi immigrants' community activities and cultural performance. I met a number of people of different occupations, ages and genders and observed their activities, talked formally and informally regarding my research, recorded their conversations and comments on issues related to the community.

In order to gain insight into the community, I found some key informants who have been living in Ottawa for a long time and know the community well. The key informants are currently related to or were the organizers of the community organizations. Ashok is one of the key informants who has been living in Ottawa for fifteen years. He entered Canada as a refugee in 1991. He was employed in different types of jobs including as a worker of Ontario Works, restaurant cook and waiter, a cable company representative, newspaper supplier, chocolate seller, food delivery person etc. He opened a grocery store but was not able to continue. His wife, two brothers and their families live in Ottawa. Ashok actively participates in the activities of different community organizations. He was the organizing secretary of the Bangladesh Association in Ottawa in 1996-1997 as a 'non-professional' representative. Moreover, he worked as the general secretary of a NGO named Bengali Community Service in Ottawa. Another key informant, Sharuk, is a federal government employee and has a $\mathrm{PhD}$ degree. He is a 'point system' category immigrant and has been living in Ottawa for thirteen years. Sharuk has been actively involved in Halaka, one of the Bangladeshi community organizations in Ottawa. Shuvo, the other key informant, came to Canada as a refugee in 1981. In 1983, he moved to Ottawa from Montreal and opened a restaurant in downtown area. He is one of the organizers of Ektara Shilpi Gosthi and Bangladesh Theatre. However, as he 
stated, he participates in the programs of all organizations. Sometimes his restaurant sponsors programs.

Restaurants and grocery stores are the main centers of some formal and informal gatherings. For this reason I spent some time in those places. Unstructured and semistructured interviews with the adult men and women provided more detailed accounts of individual feelings of ethnic identity and their perceptions of how they are seen by others.

Snowball sampling was one of the methods for the fieldwork. Snowball sampling is a method for identifying and sampling or selecting the cases in a social network. Snowball sampling begins with a few people and spreads out on the basis of links to these initial people. I have interviewed fifty four people of different occupations, genders and of different ages. Thirty one of them were interviewed for more than an hour. I have recorded the life histories of eight people in order to examine the history of the Bangladeshi community in Ottawa- with a focus on the development of the community. The experiences of these individuals differ from each other, so special attention is paid to ensure representation of gender, class, category of immigrants, etc. All of the names used in the research are pseudonyms.

\subsection{An overview of the participants of the study}

Among the fifty four people I have interviewed, there are fourteen 'professionals', nine business owners, twenty one workers in restaurants and stores, three students and seven unemployed. The professional respondents included a university professor, three federal government employees, and nine private sector employees. A coaching centre owner is also 
included as a 'professional' respondent. There are two female participants included in this category. One of them is a federal government employee and the other is a private sector worker. The rest of the professionals are males. Seven among the nine business owner respondents are restaurant owners. One of them is a grocery store owner and the other sells Tshirts in a shopping center. All of the business owners are male. During the study I have not found any Bangladeshi female business owner in Ottawa.

Among the participants there are nine store workers who work in the Bangladeshi owned restaurants. Two of them work in Indian restaurants. Seven respondents are the cooks and the others serve foods. Eight store workers participants work in franchise restaurants and two among them work in other than the food stores. Most of the Bangladeshi and Indian restaurant workers are male. Only one of the restaurant worker included in this study is a female. On the other hand six among the eight franchise restaurant workers are female. Five out of the seven unemployed people are women. Three university students participated in the study, two of them are male and the other is female. None of the people I have interviewed were born in Canada. But a few of them came to Canada when they were very young. Among the nineteen home owners respondents there are thirteen 'professionals', four business owners. Two of them work in other areas. A total of twenty eight participants live in rented apartments and seven people live in low income city housing. 


\section{Chapter -3: History and Background of Bangladeshi immigrants}

The state of Bangladesh became independent in 1971 after a bloody war against the Pakistani army. For this thesis, the history of Bangladesh is written mainly on the basis of secondary sources. Bangladeshi immigrants' history in Ottawa is written on the basis of immigrants' experiences in Ottawa. A brief history of Bangladesh is important in this research because the Bangladeshi immigrants are aware of the history of Bangladesh; and the incidences and ideologies of Bangladesh work as major phenomena in the identity formation of Bangladeshi immigrants in Ottawa. Bangladeshi immigrants' adaptation in Ottawa is also discussed in this section.

\subsection{A Brief history of Bangladesh:}

The physiography of Bangladesh is characterized by two distinctive features: a broad deltaic plain subject to frequent flooding, and a small hilly region crossed by swiftly flowing rivers. The country has an area of 144,000 square kilometers and extends 820 kilometers north to south and 600 kilometers east to west. Bangladesh is bordered on the west, north, and east by a 2,400 -kilometer land frontier with India and, in the southeast, by a short land and water frontier (193 kilometers) with Myanmar. On the south is a highly irregular deltaic coastline of about 600 kilometers, fissured by many rivers and streams flowing into the Bay of Bengal (Baxter 1984:2, Nicholas \& Oldenburg 1972:17).

Bangladesh is noted for the remarkable ethnic and cultural homogeneity of its population. Over 98 percent of its people are Bangalis; the remainders are Biharis or non- 
Bengali Muslims, and indigenous tribal peoples. Bangladeshis are particularly proud of their rich cultural and linguistic heritage because their independent nationhood is partially the result of a powerful movement to uphold and preserve their language and culture. Bangladeshis identify themselves closely with Bangla, their national language (Nicholas and Oldenberg 1972:14).

Nearly 83 percent of the people are of the Muslim religion: Bangladesh ranks third in the world's largest Islamic nations, following Indonesia and Pakistan. Sunni Islam is the dominant religion among Bangladeshis. Promulgated in June 1988, the Eighth Amendment to the Constitution recognizes Islam as the state religion. Religiously Hindus constituted the largest religious minority at about 16 percent; other religious minorities included Buddhists and Christians (O’Donnell 1984:3).

The country is one of the most densely populated countries in the world with about 140 million people. While the land that is now called Bangladesh is a very old Banglaspeaking populated area, only in 1971 it was freed from foreign domination. From 1757 to 1947, the country was controlled by the British Empire. During this period Bangladesh was the eastern part of the larger province of India known as Bengal or Bangla. In 1947 India was divided into Pakistan and India. Bengal's western portion is predominantly Hindu; when the British left it became a part of India, which is also predominantly Hindu. East Bengal, with a largely Muslim population voted to become the part of a newly formed state called Pakistan, whose people were mostly Muslim and whose two halves, West and East, were divided by eleven hundred miles of India (Novak 1993:15). The East Bengal area became independent of 
Britain as a province of Pakistan, but to the majority of east Pakistanis this would not prove to be the independence they desired (Bhattacharjee 1973: 28). They believed that they had become colonized once again, this time to the Muslim state they had supported strongly during the partition of India. Their grievances led eventually to the dissolution of united Pakistan. A number of issues dividing the two wings of Pakistan came to the forefront soon after independence. Bangladesh became independent of Pakistan in 1971 after a bloody war.

From 1947 to 1971, though Bengalis in East Pakistan were the majority, they were ruled from Pakistan's capital of Islamabad in the West by Pakistanis who, while Muslim, were of different ethnic origins, namely Punjabis, Pathans, Sindhis, and Baluchis. Moreover, the Bengalis were not allowed to use their native Bangla language; they were forced to learn $U r d u$, the language of the North Indian Muslims (Biharis) that had been chosen as Pakistan's state language for its supposed 'Islamic' character. Many Bengalis viewed this prohibition as a symbol of West Pakistan's disregard for Bengali culture and identity. The linguistic cultural identity of the Bengalis of former East Pakistan provided the impetus for the freedom struggle in Bangladesh. The Awami League, a strong vocal proponent of self-governance of Bangla region won the national parliamentary election in 1970 but the Pakistani rulers refused to hand over the power to them. Many people of Bangladesh demanded that power be handed over and called for a non-cooperation movement. On the night of March 25th, 1971, the Pakistan Army launched a terror campaign calculated to intimidate the Bengalis into submission. Within hours a wholesale slaughter had commenced in Dhaka, with the heaviest attacks concentrated on the University of Dhaka and the Hindu consolidated area of the old town (Imam 1990: 27). Bangladeshis remember the date as Swadhinota Dibosh i.e., a day of infamy 
and liberation. The Pakistan Army came with hit lists and systematically killed several hundred Bengalis (Imam 1990:9). At the same time they disarmed the Bengali speaking members of the Pakistani armed forces and police forces, killing them in hundreds. Sheikh Mujib, the main leader of the Awami League was captured and flown to West Pakistan for incarceration.

According to many writers (Novak 1993, Nicholas and Oldenberg 1972, Moniruzzaman 1988) during the war in 1971, the Pakistani army killed three million people of Bangladesh, raped two hundred thousand women, and burnt thousands of houses. An immense flood of East Pakistani refugees, between 8 and 10 million according to various estimates, fled across the border into India. To fight against the Pakistani forces the Bengali members of the armed forces and the common people formed a special force called Mukti Bahini or the freedom army (see appendix for a glossary of the Bangladeshi terms and events discussed). After nine months of brutal war the Pakistani army surrendered to the Mukti Bahini and their Indian army supporters in December 16, 1971 (Moniruzzaman 1988:119). This day is observed in Bangladesh as Bijoy Dibosh (i.e., victory day). During the war most of the Islamic parties in East Pakistan supported the Pakistani invasion and collaborated in the offfensive. Some of them formed militant organizations such as Razaakar (i.e., Volunteer), Al-badr (i.e., peace keeper), Al-Shams (i.e., sun army) and fought against the Mukti Bahini and killed many Bengali intellectuals who supported the independence of Bangladesh (Imam 1990:24). They vowed to fight against the Mukti Bahini and said that it was the conspiracy of India against Pakistan and Islam. During the last few days of the war the supporters of the Pakistani forces killed a number of the intellectuals who included university teachers, doctors, 
poets, writers, singers and other professionals who supported the freedom fight in their respective capabilities (Imam 1990:6). The main target of the Pakistani army and their supporters were the relatives of freedom fighters and non Muslims, especially the Hindus (Imam 1990:25).

The creation of Bangladesh as a sovereign nation in 1971 initiated a new phase of identity. The independent country initially banned religion in politics. But soon after liberation, in 1975, Sheikh Mujib, the leader of the 'Liberation War' and the president of the country, was assassinated by a section of the army. Almost all of his immediate family members and some leaders of his party were also killed. The army took control and power and the leaders and the supporters of the Awami League were arrested and imprisoned. To gain support of the Islamic parties army rulers amended the constitution, lifting the ban on the Islamic parties. Those who opposed the liberation now made the best use of amendment and organized themselves. Eventually they came in power in the present coalition government since 2001. In 1988, the then military government declared Bangladesh as Islamic country. In the process of Islamization of the country, using Islam in politics, both religion and the language have appeared as the two most important elements in the formation of national identity (Baxter 1997:152). Though secularism was the guiding ideology in the war of liberation, religion became an important factor soon after independence. People of Bangladesh are still divided between supporters and opponents of the liberation war. 


\subsection{A General Idea about Bangladeshi Immigrants in Ottawa}

Bangladeshi immigrants immigrated to Ottawa in various ways. There are different categories of immigrants such as "point system" category, sponsored family category, business category and refugees. Bangladeshi people's immigration processes in Canada and their adaptation in Ottawa are discussed in this section.

\subsubsection{The processes of Bangladeshi people's immigration in Canada}

As stated, Bangladeshis started to immigrate to Canada in the $1960 \mathrm{~s}$, when the Canadian government introduced a new system (i.e. "point system") of evaluation for immigration. Besides the professional immigrants, there are some other categories of immigrants, such as sponsored family category, refugees, and business category. As mentioned, whatever the process of entrance, after a time period, the immigrants can receive Canadian citizenship. However, the group is not homogeneous as there are many differences within the community, such as length of residence in Canada, categories of immigration, levels of education, gender, and generation and other distinctions that may be recognized in Bangladesh. An overall discussion about the process of immigration of Bangladeshis in Canada, their employment, organizations, takes place in this section.

Some of the major political problems in Bangladesh such as the 'liberation war' in 1971, the assassination of the first president and the leader of the 'Independence War' in 1975, and military rule from 1982 to 1990 affected the life of countless people and some left the country. As stated, the Pakistani army killed three million people, raped thousands of women, and burnt houses in 1971. In particular, those who are identified as Hindu and the 
youths were their main targets of killing because India, where the majority of the people are Hindu, supported the fight against the Pakistani army and trained the Mukti Bahini (freedom army). Many respondents in this study informed that thousands of people left the country during the war and soon after the war. In 1975, the president of the country was assassinated by a section of the army. A number of people including the Mukti Joddha's (freedom fighters) left the country for fear of imprison and torture. In 1981, the former army chief and then the president was killed by a group of army again and a few days later the military took control and held power until the end of the 1990. That was the longest military rule in Bangladeshi history and there was a 'democratic movement' against the military rule. According to the majority of the respondents a number of people were killed, tortured, arrested, and imprisoned by that time. Throughout the period people tried to flee the country for Europe, North America and other parts of the world. The next major emigration happened in 1991 when the military government was ousted from power through a 'democratic movement' which culminated in a mass upsurge. A number of the supporters of the military government, including cabinet ministers and MPs, fled the country.

Most of the Bangladeshi refugees in Ottawa arrived during these political periods. The majority of the refugees included political leaders and workers, government officials in different foreign missions, writers, and journalists. According to the respondents many of them were really the victims of the political conflicts. After arriving in Canada, they described their situation that they were in danger and would be in trouble if they go back to Bangladesh and received refugee status in Canada. A number of the Bangladeshi refugees in Ottawa first came to Montreal, having the impression that it would be easier to obtain permission to 
become a refugee in Montreal than in other areas. Another reason to come to Montreal is that some of their relatives or friends lived in Montreal. However, none of them understood French and it was not easy to find any kind of job there. For that reason they moved to Ottawa. There are a number of family category immigrants who live in Ottawa. Most of their sponsors are their spouses. There are different types of expenses for some of the family category immigrants. For example, one of the respondents, Fizu, paid a great deal of money for a bride price because his wife was a Canadian immigrant. He paid this high price in the hope of becoming an immigrant to Canada.

On the other hand, through the 'point system' category people continually immigrated. Regardless of the process of entering Canada, almost all of them are urban middle-class people with some education. Almost all of the respondents said that they spent a significant amount of money (three hundred thousand to eight hundred thousand taka, the unit of Bangladeshi currencies. A Canadian dollar is equivalent to forty to fifty taka) to become an immigrant or a refugee in Canada. They thought that it was a great opportunity for them to enter Canada and they would earn a decent living. For example, Shahu sold his family house in Bangladesh to obtain the money needed to come to Canada. He thought that he would earn money to buy a new house for his family members. However, after seventeen years the family members in Bangladesh are still living in a rented house, and he is not able to buy a house for them. Quite a few of the participants in the study seem to be disappointed in Canada. The literate people, who do not have a job related to their area of expertise, seem to be more disappointed than the others. Quite a few 'point system' category immigrant respondents think that they deserve better jobs than the ones they are doing currently. For instance, Joba was a 
university teacher and did her $\mathrm{PhD}$ in from an Austrian university. Her husband, Jaman, also completed his MSc in from the same university. Joba has had no employment for the past two years, while Jaman was working as a loading person in a grocery store. Both of them lost their previous jobs in Bangladesh. They spent almost all of their savings to immigrate to Canada. There are some different pictures of employment. For example, Shiha, one of the participants, has worked as a restaurant worker for the last fifteen years in Ottawa. His wife Shama has also been working for the last few years. Last year they moved into a 'low income apartment' of Ottawa housing. They found that if both of them work, they have to pay more for house rent. So, one of them quit their job and started taking care of their baby. They argued, "we have to pay almost all of our income for the housing. So we decided that one of us to stay at home to take care of our baby".

When asked if they were so disappointed with their lives here would they return to their home country, almost all of the participants in this study said that the system of education in Canada is better than Bangladesh and life is more secure here. There is no violence in the educational institutions in Canada as there is in Bangladesh. On the other hand, almost all of the respondents lost their previous work positions in Bangladesh and as they stated it is very uncertain to find a suitable job over there at this time. According to most of the respondents, it is impossible for any of the immigrants to do any kind of manual labour work such as a restaurant worker in Bangladesh. The payment of this type of work is very low and only gareeb manush (i.e., poor people) can do the kamlagiree (i.e., manual labour). As stated, most of the respondents are from urban middle class; they do not think they belong to the category of gareeb manush but rather that of dhonee manush (i.e., rich people). 
Some of the 'point system' category immigrants and their family members have education-related jobs. There are a number of engineers, teachers, doctors and other professionals. However, most of the refugees, their families and some of the 'point system' category people work in the restaurants as waiters or cooks, in other food stores, or as taxi drivers. Most of the participants try to find a job but some of them do not find any and live on social assistance. Some of the community members are restaurant owners. Almost all of the restaurant owners came from the greater Sylhet district, the north-eastern part of Bangladesh. According to the restaurant owner respondents, a large number of people from that area are living in England and the restaurant business is one of the successful businesses of them. Some of the restaurant owners in Ottawa lived in England and worked in the restaurants there. Some of their relatives from England initially supported them by giving money and by sharing experiences. All of the Bangladeshi restaurant workers in Ottawa originally are from Bangladesh. There are eleven restaurants in Ottawa owned by the Bangladeshis, but all of them are named as Indian restaurants such as Tajmahal (a monument in India), Light of India, Passage to India, Nupur Indian Restaurant, Mukut Indian Cuisine, and Monimahal Indian buffet. The restaurant owner respondents informed that Indian food is known to the most of the people in Canada. However, Bangladeshi food, like the name of the country, is unfamiliar to those people. For this reason, to attract customers, they named the restaurants as Indian rather than Bangladeshi names. Apsu, one of the restaurants owners, stated that the foods served in the restaurants are not a food of any specific area of the Indian subcontinent. It is a combination of Indian, Bangladeshi, Pakistani, and Sri Lankan food. Some of the foods, according to Apsu, are cooked specially for the Canadian people in a 'Canadian way'. For 
example, as Apsu said, none of the sub-continental people cook spinach with cheese but the Canadians like this item. For this reason they cook these types of food in their stores. There are differences in preparation of food between the restaurants and at the household. These differences are in selection and combination of the items, process of cooking and selection of the amount of spices. All of the cooks and most of the waiters of the restaurants are male. Some of the Bangladeshi people in the community organize their family gatherings such as birthdays and marriage anniversaries in these restaurants.

There are few Bangladeshi grocery stores in Ottawa who sell Bangladeshi fishes, spices, vegetables, and pickles. They are located in different areas of the city. Only one of them, Desh Grocery, is named in Bangla. The name of the other grocery stores are Asia Bazaar, Madina (a city in Saudi Arabia and holy place for the Muslims), and Al-Jazeera (a TV station in Qatar). The main reason behind the names is to attract people from different areas of Asia and the Muslim people from different origins. The stores also have videos of Bangladeshi movies, dramas, and songs. People can rent the videos for three to seven days. Some of the stores have Bangladeshi dresses such as sharee, lungi, panjabi, fotua and have hand-made Bangladeshi show pieces such as flags, model etc. All of the grocery stores sell some Bangla newspapers printed in Toronto, Montreal, or New York. The major sections of these newspapers contain the news of Bangladesh and articles of the prominent columnists reprinted from the leading Bangladeshi newspapers. In the articles, majority of those columnists either support the government in power in Bangladesh which is the 'Islamist' coalition or oppose its ideas and uphold 'secular' political views. Most of the Bangladeshi immigrants buy their meat and fish from Bangladeshi grocery stores in Ottawa. It is widely 
publicized that the beef and chicken from the stores are halal, which means they are slaughtered in the Islamic way.

Most of the families in Bangladesh live with their joint family members and some of the Bangladeshis in Ottawa maintain this tradition of living. Parents, brothers, sisters, their spouses and the children live together in the same house. Almost all of the houses of the community contain some of the symbols of Bangladesh such as a flag or map of Bangladesh, hand-made showpieces such as pakha (manual fan), langol (plough), Dheki (rice crasher), rickswa (manual three wheeler), hurricane (one kind of lamp) etc., paintings of prominent artists of Bangladesh, photographs of natural scenes such as village, paddy fields, river, fishing, boat etc., portraits of political leaders, the audio and video cassettes of Bangla songs and movies. Many of the Muslims have some Islamic symbols in their houses such as a portrait of the Qaba (the prophet Mohammed's grave where millions of people gather once a year from all over the world) and some Arabic scriptures from the Quran (the holy religious book of Muslims). However most of the participants keep both cultural and religious symbols in their houses. All of the participants said that they cook their own food, but women are mainly responsible for the cooking. Some of the men help in cooking, which is not a common practice in Bangladesh. Although the men cook food in the restaurants, they do not cook at home. Rice, meat, fish and vegetables are the major food of the Bangladeshi immigrants. They use various spices for the dishes. Most of the Muslims and Hindus avoid pork items. Only one respondent, Jong, is from a different ethnic group known as Chakma, religiously Buddhist and hence they are free to eat pork items. 
People usually choose their spouses within the community. Almost fifty percent of the married respondents have married a person in Bangladesh chosen by other family members, and most of the time the couple never had the chance to meet each other before their marriage. Once married, the spouse who lives in Canada normally sponsors the other spouse to come to Canada. Those who live with other family members, especially with their parents, try to find a bride or groom from the community living in Canada. Only two of the respondents, both of them are male, married non-Muslim women outside the Bangladeshi community. One of them, as stated by the respondent, converted to Islam. The Bangladeshi immigrants usually invite each other in their homes. Generally the host cooks all of the major food. Sometimes guests bring deserts, or any other items of food.

Bangladeshi immigrants construct different community organizations in Ottawa. In doing so, they tend to select some political and religious ideologies as defining them. The ideologies are related to the political and religious values in Bangladesh. Some organizations in the community are actively reproducing and promoting these values through their activities. Though all of the respondents are not equally involved in the process of constructing community organizations, they have connections to those organizations. The majority of the respondents attend some of the public functions arranged by the organizations. However, not all of the participants in the study attended religious ceremonies or cultural activities arranged by the community organizations. 


\subsubsection{Adaptation in the new environment}

According to the respondents, adaptation to a new and unfamiliar environment is a very important factor for the Bangladeshi immigrants. After arriving in Ottawa, Bangladeshi immigrants face different types of problem in the new environment. It is important to know how they face the problems.

\subsection{2a Making a living}

Most of the participants said that, they tried to establish contact with compatriots living in or around Ottawa before immigrating or after arrival. Some of them decided to come to Ottawa when they were able to find relatives or friends living here. They count heavily on these familiar people for any kind of help associated with their settlement. Usually these familiar people extend various forms of assistance ranging from receiving the incoming immigrants at the airport, arranging accommodations, finding a family physician, applying for a health card and applying for a Social Insurance Card. The majority of the respondents initially found a residence with the assistance of some of these familiar people. Within the first few days in Ottawa, a number of the participants were living in their compatriots' place.

For example, Shoha came to Ottawa because one of his distant cousins lived in Ottawa. He lived in his cousin's house for more than two months. By this time Shoha learned how to use transport, how to go to a doctor, how to seek help in an emergency situation, etc. On the other hand, one of the respondents Sanzu, brought an address and phone number of his friend's uncle whom he never met before. However the person moved out from Ottawa before Sanzu arrived. He along with his wife and his two year old baby had taken shelter in the 
Salvation Army Shelter Centre. After a week he found a Bangladeshi man in a shopping centre and shared his story with him. Though they were not known to the person, he took the family to his one bedroom apartment. They lived there for sixteen days. He arranged an apartment for the newcomers and helped them to buy their furniture and other belongings. Some of the people in the community are known to all as they help any of the community members especially the newcomers. Golap is well known for his activities in helping newcomers. For this reason some of his friends call him as Mohan Golap (i.e., great Golap).

\subsection{2b Finding Employment}

Bangladeshi immigrants work in a wide range of jobs. To find employment, the newcomers seem to be relying heavily on the community members. Professionals try to find other Bangladeshi-Canadian professionals who can help them in achieving employment. On the other hand, those who try to obtain job in restaurants or stores, search out compatriots who are working in the same areas. Almost all of the respondents believe that it is not possible to find work without any reference from the concerned work area which they call mamar jor (i.e., maternal uncle's reference). If the immigrants in the professional category do not find work related to their field of expertise for months, they try to find a job in other areas and make networks with compatriots who are working in those places.

\subsection{2c Other adaptation factors}

The newcomers usually develop a relationship with the people who help them search out housing, employment and other issues related to their settlement. In some cases 
ideological differences may affect the relationship but most of them maintain a personal relationship.

The majority of the respondents end up working in lower paying jobs and reported that they were unhappy. According to most of the lower paying workers, they have come to realize that it is very difficult to maintain their lives with this meager income. Quite a few of the participants stated that they always have to do pai pai hisab (i.e., count every single penny). A number of them need to send money to their parents or family members back home. Therefore, it is difficult to send money to them and sometimes this affects the relationship among the family members. In this regard, one of the respondents Adil stated:

...when I was a single, I was able to send money to my mother and brothers every alternative month. My living cost was low. I shared my apartment with two other people. ...I got married and brought my wife in Canada. Now I am father of a girl. My living cost is high but income is almost same. It is really difficult to send money for other family members. ...My brothers and other relatives believe that I am not sending money because of my wife. For that reason they do not like my wife.

A number of the respondents say that they can not afford to visit their family members due to travel expenses. Often, they have to wait for years to save a sufficient amount of money for a visit to Bangladesh. According to the respondents, for a round trip to Bangladesh, the plane fare itself costs almost two thousand dollars per person.

\subsubsection{Expectation and Status dislocation}

For the people of Bangladesh, immigrating to bidesh (i.e., foreign country) is often equated with going to the swapner desh (i.e., dream land), associated with economic solvency 
and a secure life (Gardner 1993:3). According to the majority of the respondents, Canada is one of the swapner desh to the people of Bangladesh. These idealistic expectations, however, do not match the reported experiences in most cases and the image of the swapner desh starts fading as soon as they discover that it is not easy to secure employment and earn money. There has been a status dislocation: the majority of the respondents, who work in the lower paying jobs, did not expect to perform such 'humble' jobs in their lives.

For example, Shoha is the daughter of a prominent business entrepreneur and politician in Bangladesh. She graduated from a university and taught at an English medium school. Shoha had a marriage proposal from a Canadian immigrant, named Ashok, who happened to be the son of a prominent physician in the same city. While proposing, Ashok claimed that he had a steady federal government job and owned a house and a car. Shoha's family readily accepted the proposal and arranged the marriage so that their daughter would have a luxurious life in Canada. However, after her arrival in Canada, Shoha said that she was disillusioned that her husband was working in a restaurant and living in a tiny apartment. She claimed that she was so disappointed that she cried for weeks. She also reported that, to fulfill the economic necessity of the family, within a few months, she started searching for employment herself. First she applied for office jobs, but to no avail. Then she applied for a position as a cashier in a few stores, but she was not considered since she did not have any relevant employment background. Next, she applied for a job in the Bangladeshi food stores and finally she obtained a job. Shoha reportedly realized that working in the food stores was the only option for immigrants. Shoha stated that she had a very challenging time negotiating the status change. She has been working in restaurants for the last eight years and never 
applied for any other job. She said that she was so uncomfortable with her status change that she typically avoided the people who knew her before. She became so angry with her family members for arranging the marriage and making her life so koster ar jontronar (i.e. horrible) that she chose not to visit them and she said that she had no plan to return to Bangladesh.

Another respondent, Rahman, was a college teacher in Bangladesh. He immigrated in the professional category and tried to obtain a professional work, but his efforts were futile. He reported that he had no idea that his prior teaching experience would be of no use here in Canada. He applied for other 'white collar' jobs without any success as well. Reportedly, being desperate, he applied for a position as a security guard, which did not secure either. Eventually, he ended up working as a cook in a restaurant.

\subsubsection{Construction of Community Organizations and Associations}

In the early 1980 s the members of the Bangladeshi community formed an organization named the Bangladesh Association in Ottawa (BAO). That was the only organization of the community arranging cultural events. It observed important days of Bangladesh such as Swadhinota Dibosh (Independence Day), Bangla Nababarsha (Bengali New Year), and Bijoy Dibosh (Victory day). From the very beginning, the organizers and the leaders of the BAO consisted of 'point system' category immigrants. According to a number of the respondents, education, wealth and connection with the officials of Bangladesh High Commission made the 'point system' category immigrants more powerful than the others. However, the emergence of the restaurants made the refugees and sponsored family category immigrants more organized and powerful. The population of this category became larger than the others. 
Restaurants and grocery stores started to sponsor the programs and tried to share in the executive committee and other committees of the BAO. Some other factors-such as political ideology and loyalty to the political parties in Bangladesh, peoples' regional origin, the ideology of the Muktijuddho (liberation war) in 1971, and debate on nationality in Bangladesh-also play important roles within the community and in choosing the leadership of the association.

According to many of the participants, there are two major political ideologies existing in Bangladesh. The first one is known as the ideology of 'pro-liberation' war. The Bangladesh Awami League (Peoples' League of Bangladesh) that led the liberation war in 1971 and the socialist parties believe that they uphold the secular ideologies of the Muktijuddho (liberation war) of Bangladesh. On the other hand, one of the sector commanders in the liberation war later established the Bangladesh Nationalist party (BNP) after the assassination of Sheikh Mujib, the leader of the Bangladesh Awami League. BNP introduced Islam as the major ideology of Bangladesh. Since its inception, according to the majority of the respondents, to gain support of the Islamic religious people BNP has been closely related to the Islamic parties who actively opposed the liberation of Bangladesh. A major ideology in this political party is to maintain Islamic values and rules. One of the prominent arguments of this political party is that years after the liberation war it is not important at all to identify the people of Bangladesh as pro or anti-liberation individuals. Rather all of the people should work together even those who were involved in opposing the 'liberation war' and collaborated Pakistani invasion. After the liberation, almost half of the time parties with this sort of ideological leaning were in power including the current coalition of the BNP and the Islamic parties. As 
stated, BNP changed the main component of the constitution which was secularism and replaced it with Islam. The amendment also said that instead of Bangalee nationality, Bangladeshi nationality should be the guiding principle of the constitution. They argued that Bangalee nationality is based on the language Bangla and a number of people in Indian West Bengal province also speak Bangla. These Indians, the majority of whom are religiously $H i n d u$, also identified as Bangalee. So, according to them Bangladeshi nationality should be the distinctive identity of the people of Bangladesh.

Those ideological issues have an impact on choosing a community leader in Ottawa. People's regional origin also plays an important role in the community. Though all of the people speak Bangla, they have local accents and vocabularies which are different from each other. For this reason sometimes it is not understandable to people originating from other parts of the country. Especially the people from Sylhet, Noakhali, and Chittagong areas maintain a distinction in terms of language.

As stated, the Bangladesh Association was the only platform where all of the community members met together at least twice a year. In the late 1990 s the community became sharply divided between the 'elites' (i.e., the 'professionals' or the 'point system' category immigrants, who had better socio- economic statuses) and the 'non-professionals' (refugees and some sponsored family category immigrants). Until the 1990s the BAO had been dominated by these 'professionals'. However, they lost their leadership in the BAO and the 'non-professionals' backed by the restaurant and grocery store owners came into control of the executive committee of the BAO through election. The association, however, has 
become inactive over last few years. A number of the participants said that during the last election in 1999 one of the candidates and his followers seized the polling centers and terrorized the voters to win the election. After the incidents majority of the respondents stopped their participation to the programs arranged by BAO.

Now people gather to celebrate their culture under the banner of different organizations. Among them Ektara Shilpi Ghosti (Ektara is a traditional musical instrument of Bangladesh, and Shilpi Ghosti means 'singers group') and Bangladesh Theatre-Ottawa arrange cultural programs, stage drama, and celebrate the national days of Bangladesh. Some of the organizers and members belong to both organizations. However, most of the members of the Ektara Shilpi Ghosti are from Sylhet region and the owners or workers of the restaurants. The organizers of the Bangladesh Theatre said that they are trying to unite the Bangladeshi people of all sectors and regions. However, according to some participants, the organizations have no specific ideological goal; some of the Bangladeshis recently formed two different organizations named Jagoruk, and Bangalee. Some of the members of the Bangalee are also the members of the Jagoruk. Though the organizations have a specific political ideology, the organizers have claimed that they are not political but cultural organizations. The main goal of Jagoruk is to practice and celebrate the 'real' culture of Bangladesh that will help to protect the community from the activities of 'Islamic fundamentalist' groups and will uphold the secular character of mainstream Bengali culture. However, some of the members think that some of the people closely related to the 'Islamic' groups have penetrated this organization. They think that Jagoruk is losing its goal because not all members are 'pro-liberation', 'progressive', and 'secular' in their outlook. In response, 
they with some other 'pro-liberation' Bangladeshi people formed the Bangalee organization, which will organize discussions and seminars on the 'real' history of Bangladesh to organize the secular people and to help the new generation to learn about their 'own' history and culture. Nijhum, who was one of the organizers of the Jagoruk, said that the idea of the organization was very much secular and constructive. However, when it attempts to perform a drama, different kinds of people entered that organization that made it simply a recreation centre, which contradicts the goal of the organization. He said that they have no time to waste because some of the issues for the Bangladeshi community are crucial. Both organizations are concerned about the recent rising of 'Islamic fundamentalism' in Bangladesh and bombings in the cultural gatherings, killing of the progressive political leaders, university teachers and writers, and the processes of 'Islamization' of the state and society of Bangladesh. It could be mentioned here that on August $21^{\text {st }}, 2004$, a wave of grenade attacks on opposition chief Sheikh Hasina's rally in Dhaka left at least 23 people killed and injured 200 including top Awami League (AL) leaders. Ivy Rahman, chief of the women's wing of the Awami League was killed among others. Hasina, who was the apparent target of the attacks carried out from buildings in front of the Awami League headquarters, escaped unscathed as activists formed a human shield to protect their leader aboard a truck (Anam 2004). In January 2005 the former Awami League government finance minister, Kibria, along with four others were killed by another grenade attack. On February $28^{\text {th }}, 2004$, a prominent writer, poet and a professor of the University of Dhaka was attacked and few days later he died. A. Khalek, a professor of Rajshahi University was brutally stabbed and died in December 2004. The killings of people and the attacks in several cultural gatherings are now common in Bangladesh (Muhammed 2005). The organizers of the Jagoruk and Bangalee said that they formed theses organizations 
to protest against these activities and to help the victims of these incidents. As they stated another goal of the organizations is to help Canadian Bangladeshis not to become the supporter of these activities.

There are some 'Islamic' organizations active in Ottawa. Halaka is one of them which seem to be more active than other 'Islamic' organizations. Halaka is an Arabic word and it means 'Islamic discussion'. The members of this organization meet once or twice a month to discuss Islamic rules, values, and customs. They also organize a Quran-teaching program for the children of the community. The goal of this organization is to uphold the Islamic values, and protect their children from the 'non-Islamic' values. A number of the respondents, most of them are 'non-professionals', said that the former leaders of the Bangladesh Association in Ottawa formed this organization in the name of Islam to continue their supremacy in the community and only the 'elites' are allowed to be members, which is why some participants refer to this organization as the 'PhD group'. According to the majority of the respondents, this 'elite' consists of people who have a $\mathrm{PhD}$ degree and/or have professional jobs and/or own a house and who immigrated to Canada as 'point system' category and their families. But the Halaka members denied the allegation and said that any of the Bangladeshi immigrants can be the member of the organization. They said that some of the Bangladeshis in Ottawa, who are not in a good position, feel inferior to the members of Halaka, and avoid the organizations' activities. The other Islamic organizations Islamic Ummah, and Islamic Society have also some activities. Islamic ummah is closely related to jamaat-e-islami, the largest 'Islamic' party in Bangladesh. According to a number of the respondents, Jamat-e-Islami was 
directly involved in the formation of pro-Pakistani armed forces during the 'liberation war' in 1971.

On September 2004 Islamic Ummah invited a Jamat-e-Islami leader from Bangladesh to Ottawa and organized a discussion meeting in the central mosque. Some of the Bangladeshis in the name of Ghatak dalal Nirmul Committee (i.e., Committee for the Elimination of Killers and Collaborators) organized a protest rally against his visit because they believe he is one of the killers in the 1971 genocide. He is also suspected to be instrumental in recent killings and bombings on the progressive people in Bangladesh. Some other Bangladeshi political parties are also having some activities in Ottawa. They organize meetings when any leader of their organizations visits Ottawa.

The organizations are very important in the Bangladeshi community in Ottawa. All of the organizations are based on issues in Bangladesh such as political ideology, regional origin, religion, etc. Almost everybody in the community has a close connection to their relatives and friends living in Bangladesh. The organizations are a reflection of people's reaction on different issues in Bangladesh. It is a common trend that always people unite under the different organizations and at the same time it is a reflection of factionalism. The following chapter will discuss the causes of creation of the organizations and the impact of these organizations in the community. It will also discuss how people select their suitable organization, who can be the organizers, and members of the community. 


\section{Chapter-4:}

\section{Choice of Ideologies, Organizations and Conflict: Construction of Local Images}

Bangladeshi immigrants construct different community organizations in Ottawa. In doing so, they select some political and religious ideologies. The ideologies are connected to the political and religious values in Bangladesh. Some of the organizations in the community are actively reproducing and promoting these values through their activities. Though all of the participants are not equally involved in the process of constructing community organizations, a majority of them attend some of the public functions arranged by the organizations. However, some of them participate only in the religious ceremonies and others like cultural activities arranged by the community organizations. Cultural, religious and other ideological choices of the Bangladeshi immigrants are seem to be related to the ideologies, politics, and incidents rooted in Bangladesh. Bangladeshis are reconstructing their local images in Ottawa.

This chapter is about the community organizations of Bangladeshi immigrants in Ottawa, the activities and ideologies of the organizations, and the impact of the organizations on the community. In the process of formation of community organizations, Bangladeshi immigrants in Ottawa construct ideological differences, create social classes and produce factions within the community. All of the produced differences are interrelated and have connection to the ideologies and events happening in Bangladesh. 


\subsection{Bangladeshi Community organizations In Ottawa}

From the very beginning of Bangladeshi immigration to Ottawa in the 1960 's, Bangladeshis have been trying to construct and strengthen their community. They continually tried to gather together by arranging different types of community activities. Those activities were arranged in people's houses, party rooms or in community centers. With the increase of immigrants they formed an organization named Bangladesh Association in Ottawa (BAO) in the early $1980 \mathrm{~s}$. This is the first Bangladeshi community based organization in Ottawa.

\subsubsection{Case Study: Bangladesh Association in Ottawa (BAO)}

When the BAO was formed, the Bangladeshi immigrant community in Ottawa was small in size, and consisted mostly of professionals. Any immigrant from Bangladesh can be a member of this organization by paying the membership fee. The membership fee is thirty to fifty dollars per year and any Bangladeshis can be an Ajeebon Sodossyo (i.e., lifetime member) of the BAO by paying five hundred dollars at a time. Without paying the membership fee any of the Bangladeshi immigrants can attend the public functions organized by the BAO but those kinds of participants do not have the voting rights in the election of the executive committee. The tenure of the executive committee is one year. However, most of the times there have been no elections; a committee has been selected by the murubbis (i.e., senior members of the community). Some of the respondents claimed that to avoid conflicts within the community murubbis took the initiative to select members of the executive committee. However, the murubbis are looked upon as 'elites' by the community people in general because the senior members with better social and economic conditions are able to be the part of the murubbis in this regard. Some of the respondents reported that the murubbis 
favored the 'professionals' in the committees because they belong to the same category. Some of the 'professional' respondents have a notion that the $\mathrm{BAO}$ should be led by them because they are able to lead the community for their efficiency in language and communication. On the other hand, the 'working class' respondents seem to have a feeling that they are ignored and excluded from the association and its activities.

\subsubsection{Construction of social classes: Struggle for power}

The $\mathrm{BAO}$ was designed to be a meeting forum for the community to provide unity. However, it became a potential source of division among the community. After a few years of the formation of the $\mathrm{BAO}$, a competition arose in terms of securing the positions in the executive committee, which led to splits in the community. Individuals who had aspirations to be the leader of the community formed different types of groups and sub-groups based on the profession, category of immigration, age, area of origin and ideologies. According to the respondents, as a result of the formation of groups, the community was divided into two major factions: one commonly called 'professionals/elites/PhD group' or Bhodrolok (i.e., gentle or upper class people) and the other group is usually referred to as 'non-professional/ working class'. Some of the 'professionals' call the 'non-professionals' as Chotolok (i.e. lower or untouchable class) or Joynal group (there are many people in Bangladesh named Joynal, but here it means rough, lower class people). On the other hand, most of the 'non-professional' respondents call the 'professionals' as Tothakothito Shikkhito (so-called educated people). Some of the 'non-professionals' said that many of the 'professionals' are Degreedharee Murkho (i.e., ignorant with degrees). 
As stated, the struggle for gaining power or leadership in the association sharply divided the Bangladeshi community in Ottawa. The leaders of both factions tried to win support in their favor. In the elections in 1990 following the division, the 'non-professionals' first managed to win some of the posts of BAO. Nevertheless, the 'non-professional' representatives reportedly felt that they were ignored by the 'professionals' in the major decision making in the executive committee of the BAO. As stated by one of the respondents, Shaif:

I was an elected organizing secretary of the executive committee of Bangladesh Association in 1992-1993. Majority of the members of that committee belonged to the 'non-professional' category. However, as the president and the general secretary of the committee were 'professionals', most of the time major decisions had been taken by them without asking or informing us. They always tried to ignore us in various ways.

This subdued sense of deception found an outlet through an open confrontation in the 1999-2000 election. A number of respondents in the study reported that the one of the president candidate, who belonged to the 'non-professional' faction, rigged the election by seizing the polling centers and terrorizing the voters by showing arms such as sticks and knives. The 'professional' respondents accused the 'non-professionals' of turning the election into an unfair vote. Most of the 'professional' participants said that after the controversy surrounding that election, they have lost their faith in the mission and vision of the BAO. They are of the opinion that the organization is no more a place for bhodrolok (i.e., gentle people) which refers to the 'professionals' in Ottawa. They reportedly have stopped sending their children to attend and participate the activities of the BAO arguing that their children would not learn anything good worthwhile from the activities organized by the chotolok (i.e., lower class) leaders of the BAO. The leaders of the 'non-professional' group defend the 
allegation by saying that it is true that they supported the president candidate in the election, but any mismanagement was carried out by a few miscreants who have no connection with them. Following that election a number of the supporters of the 'non-professional' group seem to be embarrassed and have stopped their participation in this organization. As a result, the organization has virtually become inactive.

\subsubsection{Emergence of religion}

As an alternative to the $\mathrm{BAO}$, a few people belonging to the 'professional' faction formed another organization named Halaka in 1992. This organization was based on Islamic beliefs and values. Seemingly out of anger, the supporters of this 'professionals' faction joined Halaka. Quite a few 'professional' respondents reportedly did not wish to be part of an organization primarily based on religion. However, as stated, they thought that the Bangladesh Association is no longer an organization which can play any positive role in the community. The 'professional' respondents reported that the attitude of the members of Halaka is more sovvyo (i.e. gentle, civilized) than those of the BAO, and they feel more comfortable in Halaka. They believe that Halaka is an ideal place for their children to socialize with other children. As stated by Upal, one of the 'professional' respondents:

I didn't want to be a member of the organization like Halaka which is mainly an Islamic organization. I do not practice Islam regularly and don't want to do so. However, I attend the picnic and similar programs arranged by Halaka. Some of my friends are involved in this organization. Most of the organizers of Halaka are literate and polite ... I don't want to participate in any program arranged by BAO and other organizations arranged by the 'illiterate' people. They are doing nothing but creating problems in the community. 
Some of the respondents stated that around the year 2000, Islam became a leading political ideology in Bangladesh and the secularist movements become weaker. In addition to this, the respondents mentioned that some global incidents (e.g., the war of Iraq and Afghanistan) helped to convince some Bangladeshi Muslims that they are oppressed and under threat in many ways. These issues led them to unite under the banner of this Islamic organization, Halaka. According to some of the respondents though Halaka formed in 1992, it became more organized after the said global incidents. As stated by Sharuk:

Most of the Muslims in the community believe that Muslims are sufferers in all over the world. The 'so-called Muslim terrorists' are created by the U.S.A. and their allies and now they are attacking Muslim countries one by one in the name of 'war on terror'. We, Muslims, are sufferers in many ways and will be sufferers in future. They (the U.S.A. and their allies) identified all of the Muslims as terrorists...so we should unite and practice Islam properly.... Only Allah (God) can protect us.

Halaka's claimed goals are to discuss and practice Islam and teach Islamic values to the community people in general and to the children in particular. Halaka emphasizes the practice of the Islamic rules and values regarding family and relationship between men and women.

The proponents of Halaka also expressed their concern about the Canadian values regarding various aspects of life, especially the relationship between the genders, particularly related to premarital and extramarital sexual relationships, and the same sex relationships. They seemed to be eager to use Islam as a buffer against the 'non-Islamic' or onoiteek (i.e., unethical) values of Canadian society. In general, the Bangladeshi immigrants said that they are worried that their children may develop a penchant for this kind of components of the 
Canadian culture when they are grown up. A section of the community members reportedly joined Halaka so that their children may be inspired by the Islamic values and refrain from adopting, as they stated, the 'non-Islamic' and 'vulgar' Canadian culture. Some personal issues such as problems in family life or disability of their children tempted some people to join Halaka so that they could draw some solace and sympathy from the persons apparently involved in the service of Islam.

According to some respondents associated to Halaka, the main organizers of Halaka in Ottawa are the former activists of a non-political Islamic organization active in Bangladesh, named Tableeg Jamaat. The respondents informed that Tableeg Jamaat focuses on uniting all Muslims in the world. The organization reportedly claims that the emancipation of the Muslims is founded upon the proper observation of the doctrines of Islam. The organization invites people to pray together and participate in its activities. The organizers of Halaka revealed that, on certain occasions leaders of the leading political parties in Bangladesh attend the programs organized by them in Ottawa.

Islamic Ummah, another Islamic organization in Ottawa organized by some of the Bangladeshi immigrants, is active. Quite a few respondents including the members of Islamic Ummah said that the organization is directly affiliated to the Jamaat-e-Islami, Bangladesh. According to the respondents, Jamaat-e-Islami is the most organized and active Islamic organization which forms part of the government of Bangladesh since 2001. This organization is also active in India and Pakistan under the same general title-Jamaat-e-Islami and some of the immigrants from those countries are reportedly also members of this Islamic Ummah. 


\subsubsection{Confrontation and negotiation of 'Islamic' and 'non-Islamic' ideologies}

All of the Bangladeshi immigrants seem to be affiliated to some political or religious ideologies in Bangladesh. As a result of these affiliations, there are confrontations within the Bangladeshi community in Ottawa, as reported. According to most of the respondents this conflict impacts the Bangladeshi community on several levels: from personal relations to the formation of community organizations. For example, 'secularist' respondents tended to blame Islamic organizations for generating fundamentalism in the community. They also claim that this type of Islamic organizations is responsible for promoting the idea of introducing 'Shariah Law' (i.e., Islamic family law) in Canada and it is also responsible for creating an 'Islamic' image of Bangladeshi people in the minds of many host nationals.

'Secularists' seem to believe that secularism inspired the erstwhile East Pakistanis to fight for 'liberation' in 1971 and therefore, it should be the main ideology of the people of Bangladesh. On the other hand, according to the 'secularists', Islam is an ideology or belief that should be practiced at the personal level and therefore religion and politics should not be intermixed. The 'secularist' respondents stated that the Islamic organizations, particularly Halaka, are politicizing religion for gaining power and maintaining their supremacy in the community. Interestingly, some of the members of the Islamic Ummah also blame Halaka as an organization for only the 'professionals' who do not adhere to the code of Islam and do not properly practice Islam. However, as they stated Islam is a religion of equality and every Muslim should have access to any Islamic organizations. As an example, the members of the Islamic Ummah indicate that the female members of Halaka do not maintain 'purdah' (i.e., covering the whole body in an Islamic way) in their daily activities and even in the programs 
arranged by the organization. However, according to the members of the Islamic Ummah, any of the Bangladeshi Muslim in Ottawa can be the member of the Islamic Ummah.

As stated, the 'secularists' in the community are trying to organize a forum to counter the Islamic organizations' active involvement in both Ottawa and Bangladesh. In the initial stage of the process of organizing, however, the 'secularists' became divided in their opinions. As a result, according to some respondents, more than one organization emerged with more or less the same motives and manifestoes. Two such organizations are Jagoruk and Bangalee. In addition, the old issues related to status or social class that resulted in two factions, namely the 'professionals' and the 'working class', played a key role in the division within the secularists. The organizations of the 'secularists' are active in staging drama, organizing musical soirees and dances. These organizations invite prominent artists from Bangladesh once or twice a year. Some of them organize programs through the participation of local BangladeshiCanadian artists. Certain members of the Islamic organization Halaka also attend these programs which tend to be strongly disapproved by their leaders. The leaders of the Islamic organizations are of the opinion that music, dance and drama are 'non-Islamic' and a 'pure' Muslim should keep away from these activities. According to them, these kinds of activities are haram (i.e, illegal) for Muslims. They also allege that the 'secularists' are attempting to uphold the ideologies of Awami League (i.e., people's league), one of the major political parties in Bangladesh. Two respondents, Sazeeb and Proteek, stated that Awami League is the largest 'anti-Islamic' party in Bangladesh and their supporters in Ottawa are organizing different types of 'non-Islamic' activities in the name of 'Bengali' culture. According to them 'secularists' are also involved in tarnishing the image of Bangladesh by identifying 
Bangladesh as a 'fundamentalist' country and categorize Islamic activities in Ottawa as 'fundamentalist activities'.

\subsection{Ideology-based organizations: response to the incidents in Bangladesh and in other parts of the World}

In recent years most of the community organizations in Ottawa are being formed on the basis of ideologies. As stated, the religious organizations in Ottawa are directly or indirectly affiliated to the Islamic organizations in Bangladesh. As stated by many of the participants, the division among the Islamic organizations ensues from a debate as to what constitutes 'pure' Islamic ideology, a debate that linked to the one occurring amongst the Islamic organizations in Bangladesh. The selection of these Islamic ideologies is a reflection of ideologies of Bangladesh, which means they are constructing the local ideological images in Ottawa. These organizations arrange programs to let the community be aware of the 'true' Islam. The motives behind these programs seem to be to win support of the community people. For instance, these organizations invite Islamic scholars from other cultures and countries to lecture on the history, culture and values of Islam. In this process, these organizations are building ties with other Muslim immigrant communities in Ottawa.

Jagoruk and Bangalee were formed in 2004 in the wake of the recent killings of 'progressive' people, including the attack on the leader of the opposition in a public meeting that killed several people, and attacks on the religious minorities in Bangladesh. The 'secularists' believe that the ruling alliance in Bangladesh is responsible for the killings. As 
the Islamic organizations in Ottawa are affiliated to the ruling alliance, the secularists seem to have reasons to believe that these organizations endorse and patronize these heinous incidents.

On the other hand, the ' $9 / 11$ ' incident and its aftermath seem to justify and strengthen the activities of the Islamic organizations. A majority of the respondents, including the 'secularists', tend to believe that because of their Muslim identity they are discriminated in job areas after the ' $9 / 11$ ' incident. This belief seems to help the 'Islamists' to justify their stand that Muslims around the globe should have only one identity i.e., they are Muslims. They seem to believe that Islam is the only ideology that can unite people against any discrimination.

\subsubsection{Factions within the organizations}

There are factions within the community organizations. As stated, there are at least two organizations operates in the name of Islam though all of them belong to the same belief of Sunni Islam. Many of the Muslims in the community do not participate in the activities of any of these Islamic organizations because the organizations have class specific identity. On the other hand, 'secularists' also formed more than one organization. These organizations are formed on the question regarding 'real' or 'true' ideologies. All of the groups believe that only they are practicing the 'real' ideologies, other groups are operating under the 'wrong' one. 'Islamists' are concerned about 'real' Islam, and divided in opinion. In the same way, the 'secularists' are concerned about 'real' secular and 'progressive' ideology and dispute amongst themselves. However, there seem to be no specific definitions of these 'real' concepts. Interpretation of Islam or the secular ideology differs across individuals and groups 
within the organizations. As mentioned, construction of social classes also has influence in the formation of the groups within the community.

\subsubsection{The organizers}

The organizations are usually initiated by a few people. Apart from BAO, the majority of the community people do not even know the names of all organizations. It may be relevant to shed some light on the arranger and leaders of these organizations. The leaders and the key members are either educated and/or wealthy men. 'Working class' people usually do not find time to be involved in these group activities. Only a small number of women are directly involved in these groups and the organizations include only one or two females in their executive committees. Females attend the public functions but usually do not attend any committee meetings; rather the male members attend these meetings.

As stated, Halaka is the organization of educated and wealthy community members. Most of the organizers of Halaka are educated and a majority of them live in their own houses. The main leadership of Islamic Ummah is educated and wealthy though a small number of 'working class' people are also involved in this organization. 'Secularist' organizations are mainly led by business owners, students and a small number of 'professionals'. The main organizers of Ektara Shilpi Ghosti are restaurant and store owners, the organizers of Jagoruk and Banglalee are also restaurant owners and educated people. Though the majority of the community people do not know the names of the organizations nor have they any involvement, most of them seem to be identifying themselves with the ideologies of these organizations. For example, Keya, has been living in Ottawa for more than 
ten years, does not know the names of all the organizations. She stated that she does not attend any of the programs of the organizations because she does not have the time to be involved in these activities. However, as she stated, she supports the organizations who are upholding 'Banglalee Sanskriti' (i.e., Bengali culture) and ideologies of the 'Muktijuddho' (i.e., liberation war) of Bangladesh. On the other hand, Shapru responded that he does not know any of the names of the organizations except the Bangladesh Association in Ottawa (BAO) and Halaka. However, he stated that if any Islamic organization invites him he will try to attend their programs because he believes that within this ' $o$-dhormer desh' (non-religious or non-Islamic country i.e., Canada), 'dhormo-kormo' (i.e., religious practice) is the only way to save himself and his family from the 'non-Islamic' Canadian values.

\subsubsection{Constructing solidarity and differences}

Though most of the Bangladeshi community people are not directly involved with the Bangladeshi organizations and their activities, they become connected to these organizations through attendance of the public functions arranged by the organizations. Friends, relatives, neighbors or co-workers invite each other in the programs. If people find the ideology of the organizations agreeable, they continue to participate in the programs. However, a concept of social class produced within the community plays a significant role in the selection of organizations. 'Working class' people usually do not attend any activities of the organization led by the 'professionals' such as Halaka. In the same way, few 'professionals' attend programs arranged by the organizations led by 'working class' people such as Ektara Shilpi Ghosti. In these programs, there is hardly any interaction across the community people 
attending the programs. People usually limit their interactions among their friends and relatives.

It is important to know why people construct their local images and confront or negotiate the ideologies. What causes are the driving forces in selection and reconstruction of this ideologies? The following sections will discuss the reasons behind the ideological choices and construction of meaning of these ideologies. It also discussed how they construct some recognition of common origin with other person or groups on the one hand, on the other how they produce spiritual, religious and political power in mind.

\subsection{Factors behind the organizations and groups in the community}

Most of the participants in this research are not involved in the mainstream political or cultural activities in Ottawa. Only a few of them are directly involved in the Canadian political parties. The main goal of all Bangladeshi immigrants who talked to me is to earn money and secure a prosperous life for the next generation. They tend to save as much as they can towards this goal. They also try to be of financial help for their parents and relatives 'back home' in Bangladesh. However, as stated, many of the respondents, especially the 'working class' respondents, are not usually able to save or send money for their parents, which often lead Bangladeshi immigrants to feel a sense of unhappiness. They tend to share their feelings and situations with community members and want to provide socialization for their children with other Bangladeshi children. The purpose behind this socialization is to nurture and uphold their 'heritage' culture. However, when it comes to explaining Bangladeshi culture, significant differences between them come to the surface. Food habits, clothing, and interior 
decoration of their houses bear a testimony of both religion and other elements of culture that are deemed important in the life of these immigrants. As stated before, Bangladeshis in general avoid pork items as it is prohibited in Islam and seem to prefer halal meats which are founds in the Bangladeshi and Muslim grocery stores. Some Bangladeshis drink alcohol secretly behind the curtains to prevent exposure to their families or community. All of the practices listed above seem to be related to the 'heritage cultural and social values' which means that they are reconstructing an image of local Bangladesh in Ottawa. Religion plays a significant role in this regard. Women generally wear traditional Bangladeshi dresses, which are seemingly a part of religious customs. The households of the community members are usually found to keep Bangladeshi flags, maps as well the scriptures from the Quran. Thus, most of the Muslim immigrants from Bangladesh recognize religion as a part of their culture which means that 'traditional culture' of Bangladesh is not an opponent of 'Islam' and vice versa. However, when Bangladeshis in Ottawa become involved in creation of community organizations, 'religion' and 'tradition' become confronting ideologies.

Almost all of the respondents allege that they are not getting better jobs or their work is not being fairly evaluated because of their different skin color or for their identity as Muslim or as immigrant. For that reason, they look forward to having a strong community organization where all Bangladeshis will be involved and in which the community members help each other to survive and settle here in Ottawa. The other important purpose of a community organization is to encourage the next generation to be aware of their 'heritage' culture. For example, Shanju stated that,

Only few of us (Bangladeshis) are living in Ottawa. We left all of our relatives back home. Other Bangladeshis are our friends, our relatives. 
But it is unfortunate that we are divided. We need only one community organization which would help people to fight against any discrimination. We need to help each other as like as a family member.

Most of the respondents are of the opinion that Bangladeshi immigrants should uphold their own culture in multicultural Canada instead of being assimilated into the mainstream of Canadian culture. Shiplu said in this regard,

Immigrants from different countries uphold their own culture in Canada and achieved a good place. For example Italian, Chinese and Somalian communities are very organized and established... their food and dresses are known to all... We also have many traditional cultural events. We can attract others by practicing them in an organized way.

However, when Bangladeshis in Ottawa formed community organizations, there were

divisions due to conflict over leadership and power. The community became divided in groups, factions, and classes. This division of community reflects the divisions in Bangladesh. Ultimately, the groups and factions used some social and ideological markers rooted in Bangladesh. These markers divided the people in Bangladesh. Some political and ideological issues are at work to divide the Bangladeshis in Ottawa as well. The major issue is related to the independence of Bangladesh and the political ideologies related to it.

\subsubsection{Political and ideological interpretation or reconstruction}

As mentioned, initially the $\mathrm{BAO}$ arranged both national and religious programs. There were no objections about the national and religious programs. According to respondents, the $\mathrm{BAO}$ used to organize the celebration of the Eid-ul-Fitr, the biggest religious festival of the Muslims. However, according to some respondents, though Eid-ul-Fitr is a religious festival, religious discussion was almost absent in this program. 
Cultural events such as songs, dance and food were instead the main attractions of the program. To observe the national days, the organization arranged seminar discussions and cultural programs. But when Islam emerged as an important factor in the politics and in the state system of Bangladesh, an organized form of Islam started coming to Canada. Then religious festivals became more religious. Religion even became important in the programs of national days of Bangladesh such as Bijoy Dibosh (Victory day), Swadhinota Dibosh (the Independence Day), Shahid Buddhijibee Dibosh (Intellectual Martyrs' day), and Bhasha Shahid Dibosh (Language Martyrs' day). Shoha said in this regard,

Bangladeshis observe Eid-ul-fitr as their cultural festival. Bangladeshis in Ottawa also maintained the trend. It was really enjoyable. But now some of the organizers of these programs try to impose hijab and purdah on women. For this reason I don't want to go to these programs any more. It is a reflection of Islamization of Bangladesh. In Bangladesh, Bengali culture is threatened by the so-called Islamic groups and all of the places of Bangladesh and of abroad are now controlled by them.

Some respondents said that religion is so sensitive that no members of the community would oppose its use in these programs. But some of the community members were angry with the situation and were concerned that the use of religion in these programs would strengthen the religious groups in Ottawa. One of the respondents, Shimul, has been living in Ottawa for the last thirty five years. He expressed significant dismay about the activities of the community. He said:

Since a long time, I have been upset with the Bangladeshi community in Ottawa. There seem to be a few people who are open-minded. At times, I do have a sense of suffocation here in Ottawa and I feel that Bangladeshi immigrants in other parts of Canada are open and progressive. Religious fundamentalism is expanding here in Ottawa. I can't speak here openly.... When the national days are featured by 
religious programs, I think there is no more hope for the community. I feel lonely in the community.

Shimul and other 'secular' respondents seem to believe that religion is merely a personal belief. They stated when they are combined, both religion and politics become 'dirty'. They give the example of the Pakistan-Bangladeshi war of 1971 where hundreds of thousands of people were killed in the name of religion. Many of the 'secular' respondents claim that almost all of the Islamic groups in Bangladesh supported the killing, rape and other inhuman activities in 1971. The Islamic groups reportedly argued that anti-Pakistan activities in 1971 were the activities against Islam and the killing of these 'anti-Islamic' activists were legitimate. Shimul added that the Pakistanis were defeated in the 1971 war but they left their supporters both at home and abroad who are using religion as a political weapon.

As stated, at the same time, Bangladeshi immigrants construct a social class within the community in Ottawa. The community was divided into two main groups -'professional' and 'non-professional' or 'working class'. Economy is a major issue in this regard but type of employment is the main factor in the construction of the classes. For example restaurant or grocery store owners are in a better economic position but they belong to the 'nonprofessional' or 'working class'. On the other hand, an educated person, even jobless, feels himself a 'professional' and belong to the upper class than the 'non-professionals'. Some of the 'professionals' with the support of others had taken the initiative to make religion the central factor of the community organization. But the 'working class' people did not have any stand against this process of 'Islamisation'. The conflict was actually for power and leadership; not for any ideology. The 'professionals' used Islam to gain support. On the other 
hand, the 'working class' used 'secular' ideology for gaining community support as well.

Shimul said in this regard:

I am an elderly professional in the community. But I have never supported the people who used Islam for their own interest and for being the leader of the community. I do not feel comfortable with those people. At the same time, I strongly criticize the non-professionals for their activities in the election. I don't support any of the activities. I am strongly against the division in the community. For that reason, I prefer living on my own though I feel very lonely at times. My problem is that many 'professionals' believe that I have a connection with the 'nonprofessionals'. On the other hand, I am always labeled as 'professional' by the 'non-professionals'.

Like Shimul, there are many people who are not involved in any of the groups. Nonetheless, they are labeled as belonging to a group because of their profession, economic condition and association with other Bangladeshi immigrants. Many of them attend the programs arranged by the organizations other than the groups allegedly led by the 'professionals' and the 'non professionals'. Two such organizations in Ottawa are Ektara Shilpi Ghosthi and Bangladesh Theatre. The organizations arrange programs once or twice a year. Usually they invite an artist from Bangladesh and arrange a music night or perform a drama.

Most of the respondents believe that they need an organization which would help people to overcome any kind of crisis. For example as they stated, the organization would extend their help for the newcomers or help in the funeral of any deceased Bangladeshis in Ottawa. However there are no such organizations in the community. Most of the respondents say that even though there was an internal conflict in the BAO, its activities helped people in various ways when the organization was functional. 
The underlying reason of the division in the BAO is not really any ideological issuerather it is a reflection of conflicts in Bangladeshi politics. Almost all of the respondents say that major political parties of Bangladesh are divided into intra-party and inter-party groups and sub-groups and the group leaders can not work together even though they have allegiance to the same party. The BAO leaders did the same thing in Ottawa. They made groups and subgroups and become involved in a conflict. Major political parties in Bangladesh define Bangladeshi culture by emphasizing either on 'Islamic' ideology or on the ideologies of 'secularism' and 'Muktijuddho'. Bangladeshis in Ottawa are also emphasizing the issues to define their 'heritage' culture which are also dividing the community in a similar fashion to what has been happening to the political parties of Bangladesh. At one point, all of the respondents have the same desire with regard to seeing their children practicing their 'heritage' culture but the definition of this 'heritage' culture differs across the community.

Almost all of the participants seem to be aware of racial discrimination in Canada. All of them are apparently anxious that there is racial discrimination in various forms. They think that after the incident of September 11,2001, almost everyone is suspicious of the Muslim identity. As Ayatul says:

I am a believer in Islam and used to go the mosque with my kids every Friday for prayer. However, my 12 year son started to refuse to go to the Mosque and wanted to pray at home. He informed that some of his class mates laughed at him and calls him 'Bin Laden'. After that incident, I developed a sense of feeling that everybody is staring at me as if I am one of the $9 / 11$ attackers. I stopped going to the Mosque. But I believe that all Muslims, and for that matter all visible minorities should be united under some banner to face this kind of psychological repression. 
Ayatul added that though no one approached him with regard to his going to a mosque, he still feels insecure. After the incident, he always feels that someone is pointing him as terrorist. Shapla, another respondent, reported:

I was an activist of the leftist (Marxist political parties) movement when I was a university student in Bangladesh and always fought against Islamic politics and Islamic fundamentalism because their ideologies are against all kind of freedom, especially freedom of women. I do not practice Islam, nor do I practice Purdah, but always wear Bangladeshi dresses. I heard bad comments at least twice after the 9/11. I am labeled by others what I actually am not. But I don't like to work with people who are using Islam for gaining leadership within the community. Islam can't work as tool of avoiding this kind pressure but we should stand here by upholding our own culture.

The respondents seemed to believe that there is no one to raise a voice against any of the racial or religious discriminations. For this reason, they do not share their feelings with regard to their sufferings. The respondents seemed to be aware of another issue: the role of the government of Bangladesh. Many of the respondents believe that the governments in power have not cared about highlighting the positive cultural and historical attributes of Bangladesh that might help enhance the image of Bangladesh throughout the world. They reported that the ruling party blames the opposition parties as to tarnishing the image of Bangladesh globally and the opposition blame the ruling parties. In the same vein, the community organizations in Ottawa blame each other as to creating a certain community image. Geetikar, one of the respondents, states this idea in the following way:

...flood, poverty, traffic jam, overpopulation and terrorism should not be the identity of Bangladesh. But the political parties in power or the opposition always highlight these things for their own benefit. They blame each other in every issue. The Bangladeshi community in Ottawa has also maintained the same type of relationships as are doing the political parties of Bangladesh. They (Bangladeshis in Ottawa) are doing nothing for the community but are producing differences and conflicts. 
Some other respondents also emphasized this issue. They argued that there are many natural events and cultural issues in Bangladesh. For example, as they stated the language movement of Bangladesh is one of the event now observed all over the world as "International Mother Tongue Day" which the majority of the people of the country take pride in.

So, when it was not possible to build a united strong community organization, constructed ideologies by the Bangladeshis started struggle against each other. The 'Islamists' are specifically encouraging Islamic ideology. They argued that in a changed global situation, specially after the incident of ' $9 / 11$ ', only Islamic identity and practice of Islam can save the Bangladeshi Muslims from 'non-Islamic' and 'anti-Islamic' activities and from discrimination and unfairness. On the other hand, 'secularists' challenge their arguments by saying that only secular ideology should be the main ideology of Bangladeshi immigrants and the culture of secularism can work as a buffer against any kind of discrimination. The 'secularists' seemed to have the opinion that the Islamic identity does not necessarily distinguish the Bangladeshis from other Muslims. According to the 'secularists' if an individual or group practicing Islam commits any misdeed in any part of the world, the responsibility in some way goes to the Bangladeshi community if they identify themselves as Muslim. Thus, the 'secularists' seem to expose the belief that religious identity only opens the door of oppression and discrimination. One of the respondents Shopee says:

.... a perfect person is he, who is secular in mind and who has the honor for other people and their professions. We are proud of those who are doing well in their profession. But the problem is that they are neither a secular person nor they have any honor for other people in the community. They are also using Islam for their own interest. They [the 'professionals] ignore the history and culture of Bangladesh. By their [the 'professionals] activities they help to homogenize all of the people 
[Bangladeshi immigrants] as only Muslim, which appears to synonymous to terrorists. These kinds of Islamic activities are dangerous liability for the community.

It seems that Halaka and other Islamic organizations support Islam as a complete code of life not just as personal belief. They emphasize the establishment of Islamic laws rather than just as personal practice. As stated by Sharuk, one of the organizers of Halaka:

...according to Quran, Allah said 'namaj kayem koro' not 'namaj aday koro'. The meanings of the words are not just following the rule of Islam but establish its code of conducts. For this reason Halaka emphasizes the discussion of Islamic code of conducts. Halaka is involved in establishing Islamic code of life within the Bangladeshi immigrants in Ottawa.

The segments of the respondents who have a chance to be members of Halaka reported that they feel proud that they are part of the 'elite' class. They stated that Halaka is the organization of Bhodroloks and 'elites' in the community. This image is also grounded in Bangladesh. By using religion this 'elite' image easily attracts the new immigrants who immigrate under the professional category. On the other hand, 'working class' people seem to have unhappiness about their situations. The attitude of the 'elites' appears to aggravate the situation. By using the sentiment that 'elites' disregard all other people, the leaders of the 'non-professional' segment achieve the support of all 'non-professionals'. A number of 'nonprofessional' respondents allege that one of the 'professional' delivered a speech in a gathering saying that professionals do not want to make any relationship with the 'working class' because they carry a smell of curry in their body. The implied meaning of the comment, according to the 'non-professional' respondents, is the 'professionals' identified working class as 'polluted' or 'untouchable'. This sort of comment apparently emanates from the idea of 
purity-pollution which is related to the caste system. Caste system is a pattern of social classes in Hinduism in the Indian subcontinent. It has kept a sense of order among people. Caste is the hereditary and hierarchical division of society in Hinduism. According to the system, the place of Brahmins is on the top society and their works are pure, on the other hand, the place of Sudras is at the bottom. The terms are also used loosely in Islam in the subcontinent (Baxter and Rahman 1996:57). In this regard Shopee said:

by using Islam, the professionals are up to creating a kind of caste system. The professionals assume the role of the Brahmins who have been dominating the Hindu communities in the sub-continent for hundreds of years. This type of system has also been established in the Muslim community in Bangladesh. They [the professionals] think themselves to be the higher caste, as Brahmins do, and see others as 'Sudras' [ the lower caste].

On the other hand, 'professionals' are of the opinion that it is difficult to maintain relationships with the 'non-professionals', many of whom have little or no education. According to some 'professional' respondents, some of the 'non-professionals' do not know how to behave with others 'properly' and therefore are often perceived as aggressive. The respondents added that it is their ('non-professionals') problem that they cannot join the organization Halaka and cannot adjust to work with the 'professionals'. Basu says in this regard:

Many 'non-professionals' attended the programs organized by Halaka. However, they were not able to continue their participation because of their lack of education. They feel uncomfortable with the discussion system of Halaka. It is unfortunate that they [non-professionals] always blame Halaka saying that it is meant only for the elites. Anyways, we [Halaka] are doing something for the community whereas others are doing nothing. Without any reason they are jealous about the activities and programs put forth by Halaka. They [non-professionals] are doing nothing but creating problems in the community. 
It seems that the division is not rigid and permanent but flexible. Many 'professionals' have their 'non-professional' relatives in the community. As stated by many of the respondents, kinship is an important factor in the traditional Bangladeshi culture. Despite the fact that people are divided in terms of political and ideological orientations in the formation of their organizations, many of them maintain relationship with each other. When a person loses a 'professional' employment and ends up doing a 'non-professional' one, he continues to keep his relationship with the 'professionals'. Simultaneously, to find a 'non-professional' job, a person may have to form relationship with 'non-professionals' in the community. The construction of classes in Ottawa is a reflection of social difference in Bangladesh. In the process of construction of classes religious interpretation plays a significant role. One of the 'professionals' Shafaq said, "God created our fingers of the hands unequally. Human beings are also different and unequal. It is God's law. We should accept the law and should maintain inequality". According to Shafaq and some other 'professional' respondents, stratifications within societies are a natural affair.

\subsubsection{Importance of local images}

As mentioned, Bangladeshi immigrants in Ottawa are not extensively involved in the Canadian political parties or cultural organizations. The majority of the Bangladeshi immigrants have an opinion regarding Canadian culture and politics and they are almost identical. Estimation of the overall Canadian society also does not differ to a great extent. The majority of the Bangladeshi immigrants, especially the 'non-professionals', have limited interactions with the people from other cultures. Apart form the time spent in the workplaces, Bangladeshi immigrants often keep themselves busy by conversing about family and 
homeland. Bangladeshi immigrants in general cherish the same aspirations. They are concerned about how they earn their livelihoods and maintain their lives. Fizu, a respondent, said:

I am always concerned about the hours and the dollars. For the last eleven years I have been in more or less the same kind of jobs, I got nothing better to do here. I hardly have any scope to think about anything else beyond my job. I find a lot of pleasures churning the memories of my country, friends and relatives.

The reasons behind alienation seem to be twofold in this study. One is the apparent lack of communicative skills, and the other is the reports of suffering from a sentiment of racial and religious discrimination. Quite a few respondents seem to lack proper communicative skills in English or French. For this reason they have a tendency to keep aloof from members of the other communities. They said that they suffer greatly in their daily lives due to the lack of communicative skills. Trisha says in this regard:

...I can't speak English at all and therefore feel shy. I take my kids to school but when it comes to speak English with the school authority, my husband handles it. I avoid the places where I have to speak [English].

Another respondent, Nishith, says:

I have been working in the kitchen of a restaurant for the last eight years. I do not earn much in terms of payment. But I dare not explore other good paying jobs due to the lack of my English speaking skills.

Quite a few respondents reported that they do not feel comfortable interacting with Canadian people due to the lack of oral communicative skills. Therefore, they seem to be more comfortable speaking and mixing with their compatriots. 
The majority of the respondents indicated that they believe they are subjected to racial and religious discrimination in their workplaces in Canada. According to these respondents, they are not treated well just because of their identity. With regard to promotion in the work place, they reportedly did not receive what they deserved. For example, Shahu stated that he has been working at a restaurant for more than seven years but has yet to receive any promotion. On the other hand, some other non-Bangladeshi workers became assistant manager of the store within three years.

\subsection{Factors behind the construction of ideologies}

The following contains a list of reasons why certain ideologies have surfaced:

\subsubsection{Social stratification}

According to the respondents, in general there exists a large difference among people in the typical Bangladeshi social structure. Wealth seems to be the prime determinant of these differences. Type of occupation also plays a vital role in determining the status of people in the society. In essence, the same notion of social status has been developed among the Bangladeshi community in Ottawa. Bangladeshi people in Ottawa cling to the notion of 'higher-status' and 'lower-status' work. One apparent difference from the social structure of Bangladesh is that the 'lower-status' workers in Ottawa are much more organized. There are quite a few highly educated people who have ended up in the 'lower-status' group and most of them are from the urban middle class back home. An incident can be reported in this respect. Some respondents said that in around 2000, a servant of the Bangladesh High Commissioner's house sought refugee status in Ottawa. He pleaded that he was subjected to torture and he would be tortured if he went home. A faction of 'non-professionals' supported his effort to 
gain asylum in Canada. The majority of the 'professionals' were dismayed about the whole affair and opined that the image of the High Commissioner of Bangladesh as well as Bangladesh as a whole had been tarnished. Two 'professional' respondents, Soheli and Shegufta, said that the 'non-professionals' have once again showed that they belong to the 'lower-status' category by supporting a Chakor (i.e., servant).

\subsubsection{Timeframe of immigration and sufferings in Bangladesh}

As mentioned, the majority of the refugees and some 'professional' immigrants came to Canada in the wake of various political crises in Bangladesh. Until 1990, many of the refugees seemed to believe in a 'secular' ideology. Immediately after the independence of Bangladesh, a couple of 'secular' political parties came into being. However, a military regime followed shortly after the independence. The people at the helm of the military regime used Islam and gained support from the 'Islamic organizations' which eventually strengthened their position. The secular segment of the Bangladeshi people reportedly suffered from the military regime. Many community people who seem to be 'better off' in Canada tend not to be concerned about what happens in Bangladesh. On the other hand, 'secular' people, who are not in a better position than they were in Bangladesh, tend to believe that formation of Islamist organizations in Ottawa means practicing 'fundamentalism' in Ottawa. Those 'secular' people tend to believe that the activities of the Islamic organizations in Ottawa are also strengthening such parties in Bangladesh. The parties also have direct and indirect connection to these organizations in Ottawa. Life events back home play a vital role in what an immigrant does in Canada. 


\subsubsection{Attacks on 'Bengali' culture in Bangladesh}

As stated in Chapter three, in recent times, people and political parties adhering to 'secular' ideologies are being attacked in Bangladesh. As stated by the 'Secular' respondents, some of the attacks are directed at the traditional 'Bengali culture and heritage' such as, gatherings of Bangla Nababarsha (Bengali New Year) and Jatra pala (kind of Drama and songs). The victims of these attacks tend to accuse the 'Islamic' political parties in Bangladesh who are often believed to be responsible for these attacks. They have valid reasons for these accusations because Islamic political parties are vocal against cultural activities. The Islamic political parties deem cultural activities such as songs, dances, music playing etc. as 'haram', which translates as 'not approved by Islam'. Some of them call the activities as Hinduanee (activities of Hindus). The target of bomb and grenade attacks include cultural gatherings to welcome the Bengali New Year, cinema halls and other cultural programs organized by the 'secular' and 'progressive' political or cultural organizations.

To raise a voice against these recent attacks, the 'secular' and 'progressive' segments of Bangladeshi immigrants are trying to organize themselves in Ottawa. As stated, the demonstration under the banner of Ekattorer Ghatak dalal Nirmul Committee (Committee for the elimination of killers and collaborators of 1971) opposing the visit of Sydee (a top-notch leader of the main 'Islamic' party namely, Jamaat-e-Islami, Bangladesh) in Ottawa is one of their activities. The demonstrators urged the Canadian government to ban any activity of this person and his supporters. The protestors argued that Sydee was in a mission to raise funds for his 'fundamentalist' party and expand its activities in Ottawa. The Islamic organizations active in Ottawa claim that these demonstrators are tarnishing the image of Bangladesh. They 
proclaimed that Islamic parties are not responsible for what incidents are happening in Bangladesh. Rather, some 'secularist' political parties of Bangladesh are responsible for these attacks. They stated that the parties trying to draw attention of the Western countries by saying that Bangladesh is becoming a 'fundamentalist' country like Afghanistan. They argued that in the Western world there has been an attempt to identify Islam as a source of 'fundamentalism' and 'terrorism'. In other words, the 'secularist' activities are viewed as labeling the Muslims of Bangladesh as 'fundamentalist' or 'terrorists'. Therefore, the 'Islamists' argue that the good aspects of Islam should be brought to light and Muslims should unite against the identifying Islam as 'terror'. They stated that only few people are involved in the attacks in different places in the name of Islam. Thus all of the Muslims should not labeled as 'terrorist'.

\subsubsection{Relationship to the political parties of Bangladesh}

As stated, Bangladeshi immigrants in Ottawa who support the mainstream political parties in Bangladesh arrange programs occasionally. Though the majority of the community people are not actively involved with these political parties, they nonetheless seem to be affiliated with certain political ideologies of these parties. It is worthwhile to mention here that all the major political parties have their student wings in all higher educational institutions in Bangladesh. The majority of the respondents have educational backgrounds in the colleges and universities in Bangladesh. Quite a few of the immigrants were reportedly involved with the student organizations. This involvement seems to have a role in the establishment of community organizations in Ottawa. For that reason there seems to be some kind of ideological affinity on the part of the community people who are not actively involved 
in any political parties. For example, Shapla was a leftist political activist when she was a university student. For this reason, though she is a 'professional' in Ottawa, she does not support the activities of Halaka. Rather she attended the protest rally against Sydee. On the other hand Sajeeb was active in the Islamee Chatra Shibir, the student wing of Jamaat-eIslami, and involved in the Islamic Ummah in Ottawa. The respondents claimed that they were involved in altercations with regard to the daily occurrences and activities of political parties they supported back home. In this way, an ideological extension of Bangladeshi political parties has been formed in Ottawa.

\subsubsection{Global incidents and their effects}

The majority of the respondents tend to believe that the ' $9 / 11$ ' incident was preplanned by the U.S.A. authority. The people involved in the attack on ' $9 / 11$ ' have been thought of as Muslims. It is usually thought by the Bangladeshi immigrants that Afghanistan and Iraq, which are predominantly Muslim countries, were invaded as a result of ' $9 / 11^{\prime}$. The majority of the respondents believe that the U.S.-led invasion of Afghanistan and Iraq was carried out to rob the Muslim countries of their oil reserves. This incident reportedly has an impact on the Bangladeshi Muslim community in Ottawa. Quite a few respondents reported that they have been harassed in various ways in the airports after the ' $9 / 11$ ' incident. Previous to ' $9 / 11$ ', traveling to Bangladesh through the U.S. had been less expensive and the Bangladeshis in Ottawa chose this option frequently. However, after the ' $9 / 11$ ' hardly any Bangladeshi has opted for this route. Participants reportedly had bitter experiences checking out through the U.S. immigration in Ottawa airport and the other airports in Canada and 
U.S.A. They tend to believe that religious identity and color of skin are the reasons for the harassment in the airports.

The respondents also seem to believe that after ' $9 / 11$ ' some Bangladeshis in Ottawa lost their jobs. Shanoor is one of them who worked as an engineer in a private company and lost his job soon after the ' $9 / 11$ ' incident. Some of the Bangladeshis also encountered many problems in finding jobs. In addition, there have been reportedly a number of changes in the Canadian immigration policy. Respondents said that their relatives are having trouble obtaining Canadian visas due to some recent amendments in the immigration policy. They tend to also believe that their Muslim identity is the reason behind such treatment. Apart from this, the attack on Afghanistan and Iraq has been thought of as an assault on the Muslims. The respondents seem to allege that the words 'Muslims' and 'terrorism' are synonymous. According to the participants the western media tend to portray Islam as a religion of the terrorist. These issues play an important role in determining the ideologies of Bangladeshi immigrants in Ottawa.

\subsubsection{Feeling of Discrimination}

According to one respondent, Ayatul, the essence of multiculturalism should be to respect people of all cultures. Ayatul stated that in reality, however, people of all cultures are not treated equally. Instead, he claimed visible minorities are considered to be treated differently. A number of respondents seem to believe that the Canadian state organizations use racial profiling to identify and treat people differently. From this, the participants thought that the state clearly is creating a line of difference among people. Many respondents are 
seemingly of the opinion that the white majority tend to think of others a 'second-class' citizens in Canada. For an example, Bina, who is a federal government employee, says that in the last three years she has never seen a white Canadian sharing her table in the cafeteria. Many respondents think that a kind of hidden oppression is in place in the Canadian society. According to a few respondents, the job applications of immigrants are discarded just because of their identity.

\subsection{Conclusion}

In sum, Bangladeshi immigrants reported that they have the same purpose in establishing organizations in Ottawa. The purposes include creating a space or forum to meet, to create an awareness of the Bangladeshi culture among the next generation, and to raise their voices against any kind of discrimination. However, when the community people talk about Bangladeshi culture and discrimination in terms of life in Ottawa, the discussion differs on the basis of individual experience and ideologies. These evaluations seem to have brought a section of community people nearer while a segment seems to have pushed further apart. Again, this process is a reflection of social and political ideologies of Bangladesh. For this reason, it is found that the formation of organizations, groups and sub-groups in Ottawa have been influenced by factors created in Bangladesh. These factors are either brought by the immigrants themselves or received through day to day communication with Bangladesh.

Bangladeshi immigrants in Ottawa are reconstructing a community which related to John Eade and David Garbin's (2002) discussion on the notion of "glocalization". The Bangladeshi immigrants are involved in a process of reconstruction, in a sense the production 
of home, community and locality. The image of these local practices aspires to undermine the hegemonic power of global forces, but these local factions tend to struggle against each other. The construction of this locality is related to a transnational link, but their operations are mostly located in Ottawa. Though Bangladeshi identity appears to be rooted in Bangladesh, a number of Bangladeshis in Canada have links with sympathetic movements across the world and see themselves as part of the Ummah, the international Muslim community. 


\section{Conclusion}

This thesis analyzed the ways in which political and ideological interpretations of locality of Bangladeshi immigrants in Ottawa are bound up with debates and incidents occurring in Bangladesh. Some of the events are bounded up with beyond the Bangladeshi national frontier to other parts of the world. To understand Bangladeshi immigrants in Ottawa evidence emphasizes the need to find out the more complex processes where local and global interweave and mutually inform one another. As stated by John Eade and David Garbin (2002), this interweaving of local and global is important to understand what has been happening rather than using the time-worn model of binary opposition between home and away, the domestic and foreign, the local and global.

The 'secularist' claims concerning Bangladesh's origin and their importance for practice in Ottawa have been challenged by 'Islamist' construction of place and people which appeal to another imagined community- the global community of fellow Muslims transcending national boundaries. The interweaving of local and global shapes the struggles which are embodied in 'glocal' space through contests over the construction of community organizations.

The leaders or organizers of the factions of the Bangladeshis in Ottawa established sharp distinctions between themselves and their opponents. They encouraged activists to emphasize the differences between 'secularism' and 'Islamism'. Furthermore even when factions united around the 'secularist'/ 'Islamist' ideological divide they shared the same 
concerns- racial discrimination, unemployment, education - and pursued similar strategies by using the local political ground and seeking to manipulate the influential decision-makers. But they did so contrasting themselves against the "other" Bangladeshi community.

The conflicts raise the issue of local and global collective memory. The elderly people are facing the challenge of what memories and ideologies should be passed on the next generation and for what reason. This also involves the contemporary politics of Bangladesh and the role of the government in power. 'Attacks on progressive people of Bangladesh', 'patronizing fundamentalism and terrorism' of the supporters and the leaders of the 'Islamist' governing parties in Bangladesh establish the logical ground for 'secularists' to oppose 'Islamist' activities in Ottawa. On the other hand, as Bangladesh becomes more formally Islamicised in response to local and wider global developments so Bangladeshis in Ottawa and elsewhere in the West come under pressure to conform to everyday practices which reflect the local/global Islamicizing development. These political and ideological changes clearly influence people's daily lives at the local level through, for example, what they eat, how they dress, and who they mix with.

While 'secularists' and 'Islamists' focus on the same local strategies for dealing with the issues like discrimination and unfairness, their paths began to diverge when they consider the reasons for choosing these strategies. 'Islamists' are much more interested in the impact of local action on a particular community's moral life by encouraging an Islamically ordered family within the 'non Islamic' environment. For secularists, struggle is involved in the reinvention of 'traditional Bengali culture'. However, this struggle is framed within 
assumptions about a secular nation state where Islam is confined to the realm of personal belief and practices and is not the basis for public action. Both of the local ideologies, 'Islamism' and 'secularism', aspire to struggle against any discrimination in Ottawa but are also involved in the conflicts against each other. 


\section{Appendix:}

\section{Glossary of Terms and Events used in this Thesis}

Bangalee: Literally Bengali-speaking people. Bangalee is the name of one of the community organizations of Bangladeshi immigrants in Ottawa.

Bangla Nababarsha: Bengali New Year. The year usually starts at mid April. Most of the people of Bangladesh celebrate the Bengali New Year as a part of their 'traditional culture'. However, some of the 'Islamists' in Bangladesh identify it as the new year of Hindus and they portray the activities concerning the new year as 'Hinduanee'.

Bhasha Shaheed Dibosh or Language Martyrs Day: One of the defining movements of Bangladesh, the Bhasha Shaheed Dibosh of 1952 was intended to establish Bengali as one of the national languages of then Pakistan. The Pakistan authority announced that $U r d u$ would be the only national language of Pakistan. Many people, especially the students demanded Bengali be declared the official language of East Pakistan and called a strike on $21^{\text {st }}$ February 1952 . During the movement police opened fire to a procession and a number of people including university students were killed. $21^{\text {st }}$ February was declared as International Mother Tongue Day in 1999.

Bhodrolok: Linked to the Hindu caste system, the term is frequently used in Bangladesh. Literally, it means respected people or gentle people. They are socially privileged and educated members of the society. The Bhodrolok abstain from manual labour. 
Bijoy Dibosh: On $16^{\text {th }}$ December, 1971, the Pakistani army surrendered after nine month long war. People of Bangladesh observe $16^{\text {th }}$ December as Bijoy Dibosh or the Victory day of Bangladesh.

Chakor: Literally slave. The term identifies the people who work as a household worker. Chakor is used in Bangladesh as a discriminatory word.

Chotolok: To identify the poor and manual labourer the term now and then used in Bangladesh. Usually this is used as discriminatory word.

Dhoni Manush: Rich people.

Eid-ul-Fitr: After a one month fasting Muslims observe the day as a religious festival every year. In Bangladesh, people observe the day as both a religious and a cultural festival. People arrange various kinds of games and cultural programs; TV and Radio channels broadcast various events in this day.

Ektara Shilpi Ghosthi: One of the cultural organizations of Bangladeshi people in Ottawa. Ektara is a musical instrument of Bangladesh. The meaning of shilpi is singer or artist; and ghosthi means group.

Gareeb manush: Poor people.

Ghatak Dalal Nirmul Committee: Literally committee for the elimination of killers and collaborators of 1971. The committee was formed in 1991 to demand the trial of the members of razaakar, Al-badr and Al-Shams, who they believe killed thousands of people including the intellectuals of Bangladesh.

Hinduanee: Activities of Hindus.

Islamic Ummah: Literally Islamic brotherhood. Islamic Ummah is the name of one of the Islamic organizations in Ottawa organized by the Bangladeshi immigrants. 
Jagoruk: Literally means waken up. Jagoruk is the name of one of the Bangladeshi community organizations in Ottawa.

Kamlagiree: Literally manual labour. Many of the participants in this study who work in stores and restaurants use this term to explain their 'horrible' working situation in Ottawa.

Koster ar Jontronar: Horrific and terrible.

Mukti Bahini: Literally means freedom force. It was mainly composed of Bengali personnel serving in the Pakistan army, the East Pakistan police, and civilians who took arms against Pakistan army in 1971.

Muktijoddha: The members of the Mukti Bahini.

Muktijuddho: War or fight against the Pakistan army in 1971.

Murubbi: Senior people.

Pai pai hisab: Counting every single penny.

Purdah: $\quad$ Covering the whole body in an Islamic way.

Razaakar, Al-badr and Al-Shams: During the war in 1971, some of the East Pakistani Islamic parties supported Pakistani army and formed some militant organizations (Razaakar, Al-badr and Al-Shams) to fight against Mukti Bahini. The organizations are accused of killing intellectuals of Bangladesh during the last few days of war in 1971. The words Razaakar, Al-badr and Al-Shams are Arabic and related to the battles fought by Prophet Mohammed in Arabia.

Shaheed Buddhijibee Dibosh or Intellectual Martyrs' Day: A few days before the surrender of Pakistani army, a number of teachers, doctors, writers, poets and other intellectuals were killed by the Pakistan army and their supporters in Bangladesh. 
Most of them were killed in $14^{\text {th }}$ December 1971, two days before the surrender of Pakistan army. Bangladeshis observe the day as Shaheed Buddhijibee dibosh or Intellectual martyrs' day.

Swadhinota Dibosh: Sheikh Mujib, the main leader of the independence of Bangladesh, declared independence of Bangladesh on $26^{\text {th }}$ March, 1971. $26^{\text {th }}$ March observed in Bangladesh as Swadhinota Dibosh or Independence Day.

Swapner Desh: Dreamland. People of Bangladesh often use this term to identify 'foreign' countries, specifically Europe and American countries.

Taka: $\quad$ Unit of Bangladeshi currency; One Canadian dollar is equivalent to about 40 to 50 taka. 


\section{Bibliography:}

Abdo, Nahla.

2002. "Eurocentrism, Orientalism, and Essentialism: Some Reflections on September 11 and Beyond", In September 11, 2001: Feminist Perspectives, eds. Susan Hawthrone and Bronwya Winter, Melborne: Spinifex Press. pp. 372-392.

\section{Abu-Laban,Yasmeen.}

2002. "Liberalism, Multiculturalism and the Problem of Essentialism". Citizenship Studies 6(4): 459-482.

\section{Abu-Laban, Yasmeen \& Christina Gabriel.}

2002. Selling Diversity: Immigration, Multiculturalism, Employment Equity and Globalization, Peterborough, Ontario: Broadview Press.

\section{Abu-Laban, Yasmeen \& Christina Gabriel.}

2003. "Security, Immigration and Post-September 11 Canada", In Reinventing Canada: Politics of the $21^{\text {st }}$ Century, eds. Janine Brodie, and Linda Trimble, Toronto: Prentice Hall, pp.284-305.

\section{Ahmed, Rafiuddin.}

1990. "Introduction." In Religion, Nationalism and Politics in Bangladesh, ed. Rafiuddin Ahmed, New Delhi: South Asian Press.

\section{Ahmed, Sanjeeda.}

1993. Discrimination and Adaptation of Immigrants: Dimensions of Bangladeshi Immigrants, MA thesis, Toronto: York University.

\section{Anam, Mahfuz.}

2004. Grenade Attacks, The Daily Star, Dhaka: August 22, http://www.thedailystar.net/2004/08/22/d4082201011.htm. 


\section{Barth, Fredrik.}

1969. "Introduction." In Ethnic Groups and Boundaries: The Social Organization of Culture Difference, ed. F. Barth, London: George Allen and Unwin, pp. 9-38.

\section{Baxter, Craig.}

1984. Bangladesh: a New Nation in Old Setting, Boulder, Colorado: Westview Press.

\section{Baxter, Craig.}

1997. Bangladesh: From a Nation to a State, Boulder, Colorado: Westview Press.

\section{Baxter, Craig and Syedur Rahman.}

1996. Historical Dictionary of Bangladesh, London: Scarecrow Press.

\section{Bhattacharjee, G.P.}

1973. Renaissance and Freedom Movement in Bangladesh, Calcutta: The Minarva associates.

\section{Dirlik, Arif.}

1996. "The Global and Local." In Global/Local: Cultural Production and the transnational Imaginary, eds. Rob Wilson and Wimal Dissanayake, Durham and London: Duke University Press, pp. 21-45.

\section{Dirlik, Arif.}

2001. "Place-Based Imagination: Globalism and the Politics of Place." In Places and Politics in an Age of Globalization, eds. Roxan Prazniaak \& Arif Dirlik, New York: Rowman \& Littlefield Publishers, pp. 15-52. 


\section{Eade, John. \& David Garbin.}

2002. 'Changing Narratives of Violence, Struggle and Resistance: Bangladeshis and the competition for resources in global city', Oxford Development Studies, 30 (2): 137 149.

\section{Escobar, Arturo.}

2001. "Culture Sits in Places: Reflections on Globalism and Subaltern Strategies of Localism" Political Geography, 20: 139-174.

\section{Esses, Victoria, John F. Dovidio \& Gordon Hodson.}

2002. "Public Attitudes Towards Immigration in the United States and Canada in Response to the September 11, 2001 Attack on America." Analyses of Social Issues and Public Policy, pp. 69-85.

\section{Gardner, Katy.}

1993. "Desh-Bidesh: Sylheti Images of Home and Away." Man, New Series, 28(1).1-15.

\section{Glynn, Sarah.}

2002. "Bengali Muslims: The New East End Radicals?" Ethnic and Racial Studies, 25(6):969988.

\section{Hall, Stuart.}

1996. "Introduction: Who Needs 'Identity'?" In Questions of Cultural Identity, eds. Stuart Hall \& Paul Du Gay. London: Sage Publications, pp.1-17.

\section{Imam, Jahanara.}

1990. Ekattorer Dinguli, Dhaka: Swadesh Press.

\section{Isajiw, Wsevolod W.}

1999. Understanding Diversity: Ethnicity and the race in the Canadian Context, Toronto: Thompson Educational Publishing. 


\section{Jenkins, Richard.}

1996. Social Identity, London: Routledge.

\section{Kabir, M. G.}

1990. "Religion, Language and Nationalism in Bangladesh." In Religion, Nationalism and Politics in Bangladesh, ed. Rafiuddin Ahmed, New Delhi: South Asian Press, pp.1827.

\section{Li, Peter S.}

1990. "Race and Ethnicity." In Race, and Ethnic Relations in Canada, ed. P.S. Li, Toronto: Oxford University Press. pp. 3-17.

\section{Muhammed, Anu.}

2005. "Islami Moulobad and Antorjatik Swarajantro" ("Islamic Fundamentalism and International conspiracy") in Prothom Alo, Dhaka: March 26. http://www.prothomalo.net/v1/newhtmlnews1/index.php?Date=2005-03-16.

\section{Moniruzzaman, Talukder.}

1988. The Bangladesh Revolution and its Aftermath, Dhaka: The University Press.

\section{Nazneen, Roksana.}

2003. 'Bangladeshi Muslims in Montreal: a case of divided loyalty', paper presented at Hawaii International Conference on Social Sciences, June 12.

\section{Nicholas, Marta \& Philip Oldenburg}

1972. Bangladesh: The Birth of a Nation, Madras: M. Seshachalam and Company.

\section{Novak, James J.}

1993. Bangladesh: Reflections on the Water, Bloomington: Indiana University Press. 


\section{O'Donnell, Charles Peter}

1984. Bangladesh: Biography of a Muslim Nation, Colorado: Westview Press.

\section{Rahim, Aminur.}

1991. "After the Last Journey: Some Reflections on Bangladeshi Community Life in Ontario" Polyphony 12: 8-11.

\section{Smith, Patrick J.}

2003. "Anti-Terrorism and Rights in Canada: Policy Discourse on the "Delicate Balance"" Arab Studies Quarterly 25(1\&2): 137-158.

Stoller, Paul. \& McConatha, Jasmin Tahmaseeb.

2001. "City Life: West African Communities in New York" Current Anthropology, 3(6): 651677.

\section{Weinreich, Peter.}

2003. "Identity Exploration: Theory into Practice." In Analysing Identity: Cross-Cultural, Societal and Clinical Context, eds. Peter Weinreich and Wendy Saunderson, London: Routledge. pp. 77-110.

\section{Wilson, Rob and Wimal Dissanayake.}

1996. "Introduction." In Global/Local: Cultural Production and the Transnational Imaginary, eds. Rob Wilson \& Wimal Dissanayake. Durham and London, Duke University Press, pp. 21-45. 